\title{
Oferta, Demanda e Nota de Corte: Experimento Natural sobre Efeitos da Lei das Cotas no Acesso à Universidade Federal de Minas Gerais*
}

\author{
Ana Karruz \\ Departamento de Ciência Política da Universidade Federal de Minas Gerais, Belo Horizonte, \\ $\mathrm{MG}$, Brasil. (e-mail: apkarruz@gmail.com).
}

\section{DEFINIÇÃO DO PROBLEMA}

D romulgada em 2012 e implementada gradualmente a partir de 2013, a Lei das Cotas (lei federal n. 12.711, de 29 de agosto de 2012; doravante, LdasC) estabeleceu um padrão mínimo para as ações afirmativas no acesso ao ensino superior federal (Brasil, 2012a). A reserva de vagas instituída pela LdasC é uma política pública de enormes proporções. Mais de 60 universidades e perto de 40 institutos federais de educação, ciência e tecnologia em todo o Brasil são alvo dessa ação afirmativa. A norma definiu quatro segmentos de acesso (modalidades) para egressos do ensino médio público. A modalidade 1 (M1) contempla pretos, pardos e indígenas de baixa renda; a 2 (M2), volta-se aos candidatos de outra cor/ raça também de baixa renda. As modalidades 3 e 4 (M3 e M4) não requerem comprovação de renda; pretos, pardos e indígenas concorrem na M3, e os de outra cor/ raça, na M4. A ampla (ou livre) concorrência (M5) atende os oriundos (total ou parcialmente) do ensino médio privado (Figura 1). Em 2016, a lei no 13.409, de 28 de dezembro, alterou a LdasC, estendendo a reserva de vagas para pessoas com deficiência ${ }^{1}$ (Brasil, 2016).

\footnotetext{
* O presente trabalho foi realizado com apoio da Coordenação de Aperfeiçoamento de Pessoal de Nível Superior - Brasil (CAPES) - Código de Financiamento 001. A autora agradece as críticas e sugestões oferecidas pelos dois pareceristas anônimos de DADOSRevista de Ciências Sociais e por participantes dos diversos eventos onde versões preliminares deste estudo foram apresentadas. Agradece também ao Setor de Estatística da Prograd/UFMG, por franquear acesso a uma parte dos dados aqui utilizados.
}

DADOS - Revista de Ciências Sociais, Rio de Janeiro, vol. 61, no2, 2018, pp. 405 a 462. 
Figura 1

Ilustração: Oferta de 100 Vagas em 2016 num Estado onde Metade da População é Preta, Parda ou Indígena

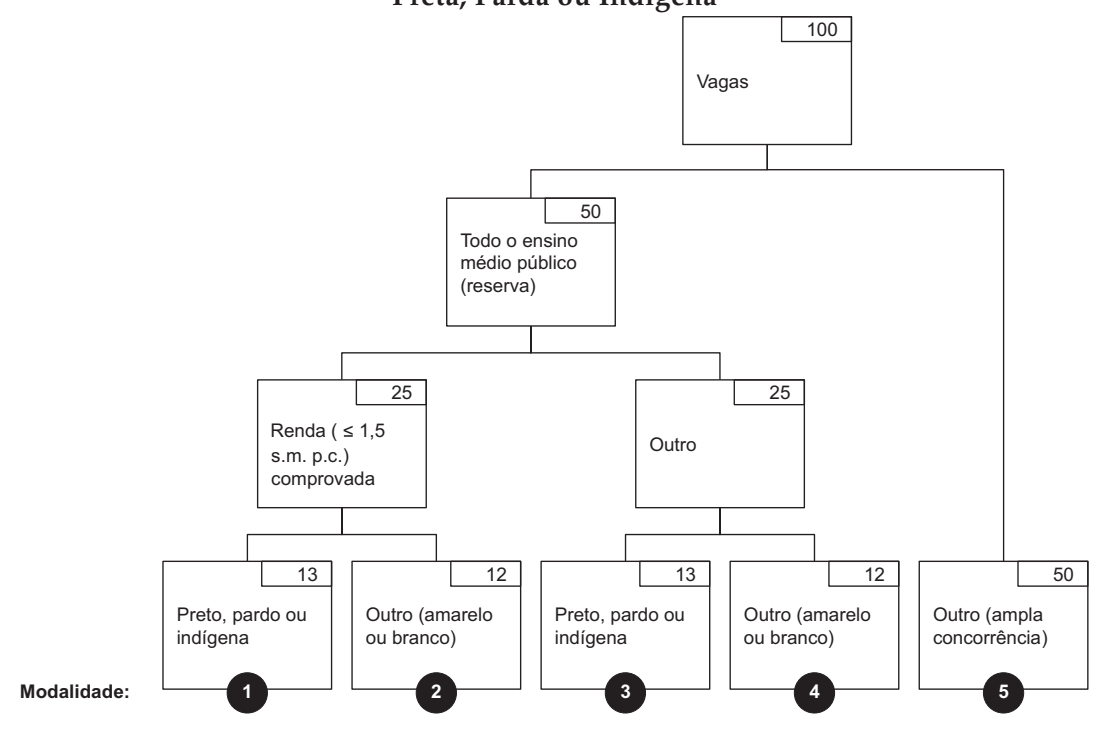

Fonte: Elaboração Própria.

A evidência até o momento sugere que a LdasC mudou o perfil dos discentes e não trouxe prejuízo acadêmico. A permanência tende a ser maior entre cotistas, e seu desempenho acadêmico na faculdade é similar ao de outros estudantes, como apontam estudos sobre a Universidade Federal de Uberlândia (Queiroz et al., 2015) e Universidade Federal de Minas Gerais (UFMG), foco de Takahashi, Caminhas e Pena $(2015)^{2}$. Do mesmo modo, pesquisas com o Exame Nacional de Desempenho de Estudantes (Enade), aplicado ao fim da graduação, indicam que o desempenho de cotistas é semelhante ao de não cotistas (Valente, Berry, 2017, com dados do Enade 2009 a 2012; Wainer, Melguizo, 2017, com base nas edições 2012 a 2014 desse exame).

Não obstante, há diversos aspectos da LdasC e sua implementação capazes de impor vieses indesejáveis à alocação de vagas, potencialmente comprometendo a efetividade dessa ação afirmativa. De partida, a política federal de cotas aplica as mesmas regras a todas as ofertas, indistintamente. Ignora, assim, a composição sociodemográfica prévia do alunado de diferentes cursos, dos mais aos menos elitizados, bem como diferenciais nos retornos materiais (e.g., remuneração de curto e longo prazo) e simbólicos (e.g., prestígio das carreiras) de cada curso e universidade, três fatores recorrentemente discutidos na literatura 
sobre acesso ao ensino superior (e.g., Vargas, 2010; Duru-Bellat, 2012; Nogueira, 2012).

Também, os percentuais de reserva são fixos e não representativos do universo dos prestadores do Exame Nacional do Ensino Médio (ENEM) $)^{3}$; enquanto $50 \%$ das vagas são reservadas para formados exclusivamente pelo ensino médio público, $83 \%$ dos inscritos no ENEM 2015 declararam se enquadrar nesse perfil ${ }^{4}$. Um ponto para reflexão é o tratamento conferido às escolas federais. Seus egressos, beneficiários das cotas, apresentam desempenho dramaticamente superior àquele de alunos das escolas estaduais de ensino médio (Golgher, 2010a, 2010b; Golgher, Amaral, Neves, 2015).

Outrossim, o limiar de renda familiar per capita (1,5 salário mínimo) é elevado: 88\% dos inscritos no ENEM 2015 que frequentaram apenas escolas públicas durante o ensino médio possuíam renda inferior a esse valor ${ }^{5}$. Como consequência, incha-se a concorrência nas modalidades que servem estudantes de baixa renda.

Ainda, a indistinção entre pretos, pardos e indígenas no critério de cor/ raça pode ser questionado (Medeiros, Deus e Mello Neto, Gomes, 2016), já que os pardos possuem chances de acesso ao ensino superior mais próximas às dos brancos e amarelos (Ribeiro, Schlegel, 2015). Outro tópico refere-se à escolaridade do pai e da mãe; apesar de não ser considerado para elegibilidade, esse atributo associa-se a variações importantes na nota no ENEM, já descontados os efeitos tocantes à escola frequentada, renda familiar e cor/ raça (Figueirêdo, Nogueira, Santana, 2014).

Entre as fontes de potenciais vieses, encontra-se o processo para distribuição dos assentos. A não obrigatoriedade de concorrência paralela intra e intergrupo tende a elevar a nota de corte (daqui em diante, NdeC) para cotistas ${ }^{6}$ (Medeiros, Deus e Mello Neto, Gomes, 2016; Nogueira et al., 2017). Uma vez consideradas as possíveis origens de distorção retratadas acima, não é surpreendente que, em diversas instâncias, as NdeC sejam mais altas para o público-alvo - fenômeno observado no Sisu 2014 (primeiro semestre) por Campos, Feres Júnior, Daflon (2014). Na UFMG, "[e]m um total de 78 cursos ofertados no SISU 2015/1, 46 (59\%) deles tiveram a nota de corte de pelo menos uma das modalidades superior à da Ampla Concorrência", pontuam Takahashi, Caminhas e Pena (2015:11). 
Ademais, restam ângulos avaliativos inexplorados, especialmente quanto ao acesso. Para além da prevista alteração sociorracial dos aprovados, cabem considerações sobre o impacto das cotas na promoção do acesso à graduação. Ainda que possam ter um papel simbólico importante, as cotas afetam diretamente apenas uma tímida proporção do público-alvo; seu alcance é limitado pela pequena expressão numérica do ensino público federal (Telles, Paixão, 2013), o qual oferece uma fatia estreita da educação superior: 8,54\% (299.234) das vagas de graduação presencial, e 1,57\% (44.047) daquelas a distância (Inep, 2016).

Do lado da demanda, apesar da alta seletividade das universidades públicas, parece existir um número razoável de candidatos bem preparados em diferentes grupos socioeconômicos, aptos a preencher as vagas oferecidas. A partir de simulações com dados do ENEM 2008 e 2012, Vilela, Menezes-Filho e Tachibana (2016) concluem que o esquema de cotas não deve trazer redução da nota média dos ingressantes nas universidades federais, pois há no decil superior de notas número suficiente de examinados com perfil para preencher as vagas reservadas aos cotistas.

Os achados de Vilela e coautores (2016) poderiam ensejar algumas interpretações alternativas. Uma delas seria que as cotas não são necessárias e não geram efeitos práticos, dada a presença de seu público-alvo entre os examinados mais bem preparados.

Outra leitura, para a qual Vilela, Menezes-Filho e Tachibana (2016) não encontraram evidência, seria que eventos anteriores à LdasC - especificamente, as várias ações afirmativas já existentes localmente, a ampliação do uso do ENEM como exame de entrada e a instituição do Sisu (em 2010) - tenham alterado o mix socioeconômico dos candidatos a uma vaga no ensino superior público. Tal processo dar-se-ia por meio de mecanismos de atração de estudantes que, embora com boas chances de aprovação, antes optavam por não tentar a universidade; os custos incidentes para quem presta diferentes vestibulares em diferentes cidades afugentariam esse público. Outro fator que poderia obscurecer efeitos da LdasC seria o incentivo a um maior esforço por parte de candidatos com perfil cotista, alvo de ações afirmativas. A LdasC intensificaria essas respostas, possivelmente já em curso, incidentes sobre a demanda por vagas.

Uma terceira narrativa, explorada neste trabalho, associa o impacto das cotas, se existente, principalmente a i) uma mudança na percepção 
de riscos do ensino superior por parte do público-alvo; e ii) variações na distribuição deste entre diferentes cursos de graduação. Os achados de Nogueira et al. (2017) são consistentes com esta interpretação; considerando os calouros da UFMG de 2010 a 2015, os autores pontuam: "Embora o perfil geral dos estudantes da universidade pareça não ter se alterado tanto, os dados analisados mostram, por outro lado, que estão ocorrendo mudanças significativas conforme os cursos considerados. Enquanto em alguns a participação de egressos de escolas públicas se elevou de forma acentuada, em outros temos um movimento inverso" (Nogueira et al., 2017:26).

O presente estudo é norteado por uma ambição dupla: formular e testar hipóteses sobre mecanismos geradores de eventuais impactos da Ldas $\mathrm{C}$ nas chances de diferentes grupos acessarem o ensino superior, e dimensionar esses impactos. Acredita-se que essa seja uma aspiração oportuna, já que o art. 7o da LdasC, alterado pela Lei no 13.409/2016, prevê para até 2022 a revisão dessa ação afirmativa (Brasil, 2012a, 2016), ensejando a realização de reflexões sobre o tema. Em particular, são perseguidas as seguintes questões de pesquisa:

1. Através de quais mecanismos a LdasC pode influenciar a alocação de vagas?

2. Em que medida a LdasC reduz desigualdades sistemáticas no acesso ao ensino superior federal?

A UFMG é o caso selecionado para estudo. Essa instituição abriga cerca de 49 mil estudantes, sendo 32 mil de graduação presencial, estes espalhados em mais de 70 cursos $^{8}$. Foi a universidade mais procurada na primeira edição do Sisu $2017^{9}$, com 171 mil inscrições para 6.279 vagas, numa média de 27 candidatos por vaga (Agência de Notícias da UFMG, 2017). Um experimento natural, com atribuição "como se" aleatória ao tratamento (neste caso, maior percentual de vagas reservadas em 2015 em relação a 2014) para indivíduos de certa idade, e uma estratégia de pareamento conhecida como fronteira de pareamento (matching frontier), possibilitam inferências causais no endereçamento das questões de pesquisa.

A próxima seção detalha desigualdades no acesso à educação superior e fundamenta as hipóteses. A terceira seção Desenho da Pesquisa reporta os dados e métodos. Os resultados são expostos na quarta seção intitulada Análises. Conclusões e implicações são discutidas na última seção, a qual é sucedida pelas referências bibliográficas.

DADOS - Revista de Ciências Sociais, Rio de Janeiro, vol. 61, no 2, 2018 


\section{CONTEXTUALIZAÇÃO}

Esta seção percorre diferentes literaturas com o objetivo de subsidiar a elaboração das hipóteses do trabalho. Primeiro, revisa a evidência sobre desigualdades na transição para o ensino superior (tanto do ponto de vista do acesso, como da seleção de cursos). Após, apresenta um referencial teórico para apuração das desigualdades no acesso, baseando-se no trabalho de Roemer (1998). Então, descreve a lógica de funcionamento da reserva de vagas (como uma política de regulação de quantidades), e conclui apresentando as hipóteses.

\section{Desigualdades no acesso ao ensino superior}

As últimas duas décadas foram marcadas por um intenso processo de alargamento no acesso ao ensino superior. Concorreram para isso o fortalecimento tanto da demanda como da oferta (Corbucci, 2014; Neves, Martins, 2016; Picanço, 2016). De um lado, um conjunto de políticas voltadas à universalização da educação básica (principalmente, o Fundef a partir de 1998, substituído em 2007 pelo Fundeb ${ }^{10}$ ) e incentivo à permanência (e.g., o Programa de Erradicação do Trabalho Infantil - PETI, desde 1996; o Bolsa Escola de 2001 e o Bolsa Família, a partir de 2003) fez crescer a população com ensino médio completo, ampliando a demanda potencial pela educação terciária. Em 2011, 26,3\% dos brasileiros maiores de 18 anos haviam concluído a educação secundária, contra apenas 11,0\% em 1996 (Picanço, 2016).

Do lado da oferta, houve um aumento marcante das vagas disponíveis (via criação de novas instituições de ensino superior, campi e cursos), redução dos preços das mensalidades e multiplicação de programas sociais para acesso (com destaque para o Programa de Financiamento Estudantil - Fies e o Programa Universidade Para Todos - Prouni, criados em 1999 e 2004, respectivamente). Em 1990, eram ofertadas 503 mil vagas no ensino superior; em 2010, já passavam de três milhões; em 2011, 15,5\% da população maior de 18 anos havia frequentado a graduação (a tendo completado ou não), contra 7,7\% em 1993, informa Picanço (2016).

Tal elevação de participação alcançou todos os grandes grupos socioeconômicos, mas especialmente os menos favorecidos. De 1993 a 2011, o percentual de brancos que frequentava ou havia frequentado o ensino superior praticamente dobrou, passando de 11,2 para $21,6 \%$. Para os negros, o acesso mais que triplicou, elevando-se de 2,8 para $9,4 \%$ no 
mesmo período, todavia ainda evidencia diferença dramática entre grupos (Picanço, 2016).

O acesso ao ensino superior é apenas uma expressão acumulada de desigualdades iniciadas nos primeiros anos de escolarização, desde a educação infantil (Duru-Bellat, 2012; Picanço, 2016). As origens sociais e o sistema de ensino frequentado na educação básica influenciam as chances de os estudantes chegarem à universidade. Essa estratificação na conclusão do ensino médio e no acesso ao ensino superior, chamada de "vertical", é fartamente documentada na literatura (e.g., Collares, 2010; Mont'Alvão, 2011, 2016; Ribeiro, Ceneviva, Brito, 2015).

Acompanham essa estratificação - e compõem sua base de sustentação - importantes diferenciais de desempenho escolar entre grupos. Com a expansão do ensino fundamental, as injustiças vêm cada vez mais assumindo a forma de desigualdades de aprendizado, as quais representam barreiras às transições mais avançadas, com marcantes disparidades por cor e nível socioeconômico, concluem Alves, Soares e Xavier (2016). Apesar de terem apresentado melhora na proficiência, especialmente no 5 o ano, conforme apurada pela Prova Brasil ${ }^{11}$ entre 2005 e 2013, estudantes pretos tendem a mostrar desempenho inferior ao de pardos e brancos. Quanto às diferenças entre alunos de diferentes níveis socioeconômicos ${ }^{12}$, elas "são enormes, e todo o avanço no aprendizado médio dos estudantes brasileiros não mudou em nada as desigualdades", apontam os autores (Alves, Soares, Xavier, 2016:61).

Ainda que os participantes do ENEM formem uma amostra autosselecionada, com trajetória de aprendizado defensavelmente mais robusta, nesse exame também ficam patentes desigualdades educacionais. A nota média dos egressos do ensino secundário público é substantivamente inferior à da rede privada; também, é tipicamente menor a dos estudantes de baixa renda e de pretos, pardos e indígenas, mesmo quando se consideram concomitantemente outros fatores como a escolaridade parental, o sexo e a região de moradia - urbana ou rural (Figueirêdo, Nogueira, Santana, 2014). Assim, infere-se que as modalidades de entrada da LdasC (M1 a M5) atendam populações com distribuições próprias de desempenho no ENEM.

A próxima subseção trata de outro processo revelador de desigualdades, a seleção de cursos de graduação. Este se combina com as barreiras ao acesso, acentuando diferenciais nas oportunidades postas aos grupos socioeconômicos.

DADOS - Revista de Ciências Sociais, Rio de Janeiro, vol. 61, n’ 2, 2018 


\section{Desigualdades na demanda por cursos}

A educação superior não é monolítica: há diferenças importantes entre os cursos quanto a dificuldades para admissão e conclusão, prestígio (do curso e da instituição de ensino), oportunidades de trabalho e expectativa de rendimento (Vargas, 2010; Duru-Bellat; 2012; Nogueira, 2012; Martins, Machado, 2015). A distribuição de indivíduos em cursos conforme aspectos de origem social e trajetória educacional é entendida como um tipo de estratificação, "horizontal", onde importa não o resultado binário de uma transição educacional (acessou ou não o ensino superior), mas sim as diferenças qualitativas dessa transição (Gerber, Cheung, 2008; Carvalhaes, Ribeiro, 2017). Explica Mont'Alvão (2016:16): “Estas diferenças podem residir nos tipos de educação - vocacional ou acadêmica -, nos tipos de instituição - universidades de pesquisa, faculdades, colleges, etc. -, assim como nos cursos e campos do saber - ciências médicas, econômicas, humanas, etc." Por exemplo, em um estudo sobre a UFMG, Braga, Peixoto e Bogutchi (2000) salientam a existência de uma importante influência do background socioeconômico dos candidatos na escolha de cursos. Ainda que obtivessem notas suficientes para aprovação em cursos "imperiais"13 (Direito, Engenharia e Medicina), candidatos de menor poder aquisitivo tendiam a procurar cursos menos seletivos. Já os concorrentes de maior renda inclinavam-se a buscar cursos imperiais, mesmo que seu desempenho no vestibular viesse a revelar deficiências no preparo.

Nos cursos de maior prestígio e expectativa de rendimento futuro, negros são menos frequentes. Dentre os graduados em Direito, Engenharia, Medicina e Odontologia, havia em 2010 menos de um negro para cada quatro brancos (Artes, Ricoldi, 2015). Pretos e pardos apresentam um padrão de decisão sobre carreira que guarda similaridades com o das mulheres, explicam Ribeiro e Schlegel (2015:138), muito em função do menor status e valor de mercado das profissões mais frequentes entre as mulheres: "Diante das dificuldades de acesso ao ensino superior, os grupos sociais menos privilegiados optariam por carreiras de menor prestígio e menos masculinas". Após analisarem dados dos Censos Demográficos de 1960 a 2010, os autores depreendem que as desigualdades de gênero têm arrefecido, contudo as raciais mantiveram-se inalteradas; os cursos de menor prestígio continuam recepcionando mais pretos e pardos. Dados do Enade (edições 2007, 2008 e 2009) examinados por Carvalhaes e Ribeiro (2017) indicam que estudantes cujos 
pais (um ou ambos) tiveram exposição ao ensino superior apresentam chances significativamente mais elevadas de frequentar cursos de maior prestígio (e.g., Medicina, Engenharias) e instituições públicas. Além de forte estratificação por gênero, os autores identificaram estratificação racial, porém em menor medida que aquela por classe (escolaridade dos pais) e gênero; brancos continuam exibindo maiores chances de frequentar cursos mais prestigiosos, e negros, os menos prestigiosos. Carvalhaes e Ribeiro (2017) aplicam modelos multivariados, condicionados, entre outras variáveis, pela proficiência em um teste de habilidade verbal.

Martins e Machado (2015) investigam as possíveis diferenças de comportamento dos indivíduos no processo de escolha do curso, determinadas por sua condição socioeconômica. Na formulação desses autores, a utilidade esperada do curso é o que define a escolha da carreira. E essa utilidade é medida pelo produto da probabilidade de o indivíduo ter sucesso em concluir o curso e o retorno esperado após a conclusão. Pela modelagem de Martins e Machado (2015), afetam a probabilidade de sucesso fatores como: habilidades e preferências, estrutura familiar, estado civil, escolaridade dos pais, trajetória escolar, renda individual, renda domiciliar, local de moradia, idade, sexo e cor. Esses autores invocam uma versão modificada da teoria do capital humano ${ }^{14}$, conhecida como teoria do capital humano heterogêneo (Montmarquette, Cannings, Mahseredjian, 2002), a qual reconhece os retornos diferenciados dos vários cursos de graduação, e propõe uma avaliação da utilidade esperada do investimento em educação, curso a curso.

São fontes para Martins e Machado (2015) dados do questionário da amostra dos Censos Demográficos de 2000 e 2010 e das Sinopses do Ensino Superior do Inep de 2012. O rendimento esperado de cada curso foi calculado com base na renda média por hora de trabalho para os graduados entre 25 e 35 anos e, em outro indicador, para o intervalo dos 25 aos 65 anos. A partir de um modelo logit condicional para as chances de uma pessoa eleger um curso superior, segmentado por quartil de renda domiciliar per capita, os pesquisadores concluem que os indivíduos do quartil mais alto de renda são sensíveis aos rendimentos esperados dos cursos (diferentemente dos demais grupos de renda), e que para essas pessoas, o rendimento no início da carreira (25 a 35 anos) influencia mais a decisão de qual curso seguir do que o rendimento esperado ao longo da carreira (dos 25 aos 65 anos). De outro lado, a concorrência no processo seletivo parece afastar os candidatos

DADOS - Revista de Ciências Sociais, Rio de Janeiro, vol. 61, nº 2, 2018 
no menor quartil de renda. Esses achados lançam questionamentos sobre a extensão da racionalidade subjacente à escolha de cursos.

A escolha racional, assim como a teoria do capital humano, modela a passagem pelo ensino superior e a definição de cursos como decisões de investimento. Raymond Boudon $(1979,2000)$ sustentou que a análise das opções de cursos baseia-se em avaliações de riscos (e.g., de ser reprovado no processo seletivo ou nas disciplinas), custos (e.g., de oportunidade do tempo, desembolsos para mensalidades) e benefícios (e.g., expectativa de renda futura, valor simbólico do curso), com parâmetros (ou pesos) idênticos para todas as pessoas. Esse modelo admite que indivíduos percebem valores diferentes para os riscos, custos e benefícios, e que esses valores são socialmente determinados, observa Nogueira (2012).

Sem embargo, Boudon enxergou as fragilidades da racionalidade na escolha de cursos - a qual estaria mais ou menos presente dependendo do grau de consciência na avaliação das alternativas (i.e., na identificação de oportunidades objetivamente viáveis, mesmo entre as pouco frequentes no meio de origem); do volume e qualidade da informação disponível (e.g., sobre as chances de acesso, a prática das diferentes profissões e as perspectivas de longo prazo); e do processo de definição de preferências entre cursos (balizado por um conjunto de referências que extrapola o meio familiar e pode aportar influências contraditórias $)^{15}$.

Nas disposições incorporadas (Bourdieu, Passeron, 1964, 1970; Bourdieu, 1979, 1998), a noção de decisão entre possibilidades de investimento também está presente, porém é enunciada não como uma escolha livre dentre um cardápio de alternativas longo e compartilhado por todos, mas limitada pela origem social do estudante. Aqui, pesam sobremaneira as oportunidades objetivas vivenciadas pelos grupos sociais, as quais influenciam tanto experiências pessoais como aspirações. Condições heterogeneamente distribuídas incluiriam a capacidade de levantar informações e identificar oportunidades (e.g., sobre custos, assistência estudantil), o apetite para risco (função do acesso a capital econômico e social em caso de fracasso), e os critérios de ordenação de preferências (e.g., valor atribuído ao acesso ao ensino superior em si, versus distinções e hierarquia entre instituições). O resultado é uma trajetória escolar aderente ao que seria estatisticamente 
mais provável para membros de um dado grupo (Nogueira, Nogueira, 2015).

Via priorização do presumível em detrimento do possível, processo chamado causalidade provável, indivíduos de grupos menos favorecidos autoexcluem-se de algumas escolhas de cursos (e.g., dos mais competitivos ou elitizados), em apreciações pouco conscientes dos custos e benefícios envolvidos (Nogueira, 2012). O ajuste recorrente das opções de investimento às condições em que a pessoa fora socializada levaria à internalização de um habitus - i.e., a um sistema de disposições incorporadas.

A seu turno, Lahire $(1999,2002,2006)$ contesta a possibilidade da construção de um habitus de grupo, visto que a vivência humana escapa frequentemente às fronteiras do meio social de origem, explica Nogueira (2012). Lahire salienta a existência de um conjunto variado de relações sociais e afetivas - e.g., na escola, na comunidade, na igreja - que complementam a transmissão de capital cultural e a incorporação de disposições em andamento dentro de casa. $\mathrm{O}$ resultado dessa diversificação de influências é incerto e idiossincrático. Apesar de mais realista, a descrição de Lahire é de difícil verificação empírica; por assentar-se na explicação idiográfica, sujeita-se a limitações de escala e a entendimentos post factum, em que se superestimam as influências alinhadas à decisão final, suplantando as contrárias (Nogueira, 2012).

Em relação ao vestibular, onde o candidato se inscreve para uma oferta antes de conhecer seu desempenho no teste de entrada, é de se esperar que o sistema de apostas e rodadas sucessivas do Sisu tenha aprofundado a racionalidade na seleção dos cursos (Campos, Feres Júnior, Daflon, 2014; Nogueira et al., 2017). As NdeC simuladas divulgadas pelo sistema antes de seu fechamento favorecem a calibragem entre os desejos vocacionais de candidatos, de um lado, e suas chances de aprovação em cursos selecionados. Buscando maximizar a probabilidade de acesso, indivíduos percorreriam sua ordenação de preferências atrás de opções "viáveis" de curso. Dessa perspectiva, ofertas historicamente menos demandadas têm sua demanda aumentada; a reboque, as NdeC tendem a subir. Tal oportunidade de ajuste de expectativas é posta igualmente a cotistas e não cotistas. Consequentemente, propicia-se um melhor "aproveitamento" das notas obtidas no ENEM, e uma redução da diferença entre $\mathrm{NdeC}$ nas modalidades de reserva em

DADOS - Revista de Ciências Sociais, Rio de Janeiro, vol. 61, n’ 2, 2018 
relação à livre concorrência, nos diversos cursos (Campos, Feres Júnior, Daflon, 2014).

\section{Uma noção de justiça para o acesso ao ensino superior}

Diversos estudos sobre desigualdades em testes de entrada e sobre acesso ao ensino superior (e.g., Duru-Bellat, 2012; Figueirêdo, Nogueira, Santana, 2014; Mendes Junior, Waltenberg, 2015) dialogam com o trabalho de Roemer (1998), o qual define justiça a partir de uma classificação de determinantes de resultado. De um lado, figuram fatores contextuais, as circunstâncias dadas ao indivíduo e sobre as quais possui pouca ou nenhuma possibilidade de ação. A desigualdade oriunda das circunstâncias reflete padrões mais gerais de disparidade social, e é injusta. Do outro lado está o esforço, a decisão determinada de empenhar-se - investir tempo, recursos materiais, energia emocional e intelectual no desenvolvimento de um resultado almejado. O esforço é variável influenciável pelos indivíduos, os quais devem ser premiados em função de sua dedicação; a desigualdade originada no exercício individual de responsabilidade (esforço) é considerada justa.

Da perspectiva de Roemer (1998), comparações de resultados entre indivíduos que vivenciaram diferentes circunstâncias são inapropriadas, e nada dizem sobre merecimento. Valorações de mérito devem ser condicionais ao tipo (ou grupo) ao qual um indivíduo pertence; esses tipos são definidos de forma a reunir pessoas que experimentam circunstâncias semelhantes. A partir dessas noções, é derivado o Axioma de Identificação de Roemer (AIR), segundo o qual duas pessoas com diferentes níveis de oportunidade, mas no mesmo quantil da variável de resultado (e.g., nota média no ENEM), condicionada ao seu fator de circunstâncias (i.e., na distribuição específica do seu grupo socioeconômico), empreendem o mesmo nível de esforço. Partindo-se da premissa de que o esforço é independente da circunstância, se o esforço deve ser recompensado (e não fatores contextuais), então o arranjo justo seria aquele que equiparasse as oportunidades de indivíduos em quantis iguais nos seus respectivos grupos.

Segundo Mendes Junior e Waltenberg (2015), a proposição teórica de Roemer (1998) deixa importantes questões não resolvidas, entre elas quais seriam as circunstâncias limitantes mais relevantes para a definição dos tipos. Ademais, o esforço pode ser endógeno - por exemplo, pela via da causalidade provável - e não livremente "escolhido". 
Assim, cotejar diretamente as chances de aprovação entre grupos, mesmo se restritas a certos quantis, arrisca a validade da análise, já que a posição relativa nos diferentes grupos não necessariamente é uma boa régua, um bom padrão de comparação (Duru-Bellat, 2012). Em algumas circunstâncias, uma performance de destaque pode ser muito mais custosa.

A subseção a seguir debruça-se sobre o desenho da LdasC, enquanto política de regulação de quantidades. A partir dessa perspectiva, e da revisão bibliográfica empreendida até aqui, são enunciadas as hipóteses, examinadas na terceira seção intitulada Desenho da Pesquisa.

\section{Lei das Cotas como moduladora da alocação de vagas: hipóteses de trabalho}

Ações afirmativas objetivam aumentar a representação de grupos específicos na fruição de bens e serviços socialmente considerados de valor. Explica Sabbagh (2011:470):

As a general matter, affirmative action is a set of measures intended to
influence the allocation of goods - such as admission to selective uni-
versities or professional schools, jobs, promotions, and public con-
tracts - through a process that takes account of individual membership
in designated groups. The goal is to increase the proportion of members
of those groups in the population under consideration, where they are
currently underrepresented in part as a result of past oppression by sta-
te authorities and/or present societal discrimination.

Desde o início dos anos 2000, diversos modelos de ação afirmativa no acesso ao ensino superior público foram experimentados no contexto brasileiro, com pioneirismo da Universidade do Estado do Rio de Janeiro e Universidade do Estado da Bahia, as quais estabeleceram esquemas sociorraciais de reserva de vagas já em 2001 (Queiroz, Santos, 2006). Até 2012, as políticas compensatórias eram elaboradas e geridas de maneira descentralizada, ao nível das instituições de ensino superior ou estados. Os modelos incluíam cotas, subcotas ${ }^{16}$, acréscimo de vagas para públicos específicos e bônus (Brasil, 2012b); naquele ano, $73 \%$ das instituições públicas (federais e estaduais) de ensino superior adotavam alguma ação afirmativa no processo seletivo, apuram Daflon, Feres Júnior e Campos (2013). Como notam esses autores, se de um lado a fragmentação decisória possibilitava adequação de modelos

DADOS - Revista de Ciências Sociais, Rio de Janeiro, vol. 61, n’ 2, 2018 
às necessidades locais, ela dificultava a visibilidade e avaliação das iniciativas.

A LdasC estabeleceu uma política de caráter redistributivo, assentada na segmentação da competição. A rigor, a reserva de vagas é uma regulação de quantidades, desenhada para endereçar falhas alocativas, como externalidades e distorções na distribuição de oportunidades (Weimer, Vining, 2004). Uma premissa mínima para que a reserva de vagas torne o acesso ao ensino superior menos desigual é que os grupos beneficiários sejam adequadamente definidos, congregando indivíduos com experiências sociais e escolares compatíveis, substantivamente diferentes entre grupos (Mendes Junior, Waltenberg, 2015). Atendido esse requisito, a disputa que ocorre dentro dos agrupamentos é mais justa que a competição num sistema sem cotas.

Tudo o mais constante, a expectativa seria que a LdasC resultasse em NdeC diferentes entre os grupos beneficiários, os quais, presume-se, possuem padrões distintos de escores; e que as NdeC fossem inversamente proporcionais ao número de condições "desfavorecidas" enfrentadas pelos elegíveis às cinco diferentes modalidades de entrada. Com a expansão dos percentuais de assentos reservados, esperar-se-ia que as NdeC para cotistas se reduzissem, alcançando quantis mais baixos na distribuição de desempenho no ENEM de cada grupo. O quanto a LdasC deveria "empurrar" beneficiários no sentido de aproximá-los da NdeC relevante (i.e., da modalidade para a qual se qualificam) é uma questão em aberto, e cuja resposta possui carga normativa, implicando considerações sobre injustiças sedimentadas, esforços relativos e a correta premiação a eles.

Mas, qual evidência seria necessária para substanciar potenciais avanços na posição do público-alvo atribuíveis à LdasC, em meio à competição por assentos? O presente trabalho endereça essa questão a partir do AIR (introduzido na subseção anterior), apesar de reconhecer as limitações desse construto. Especificamente, entende-se que se i) as preferências são estáveis dentro de grupos, e ii) as modalidades de entrada via LdasC são capazes de identificar grupos socioeconômicos educacionalmente desiguais (como sugere a subseção sobre desigualdades no acesso à educação terciária), então a evolução das chances de admissão à UFMG dentro dos grupos pode revelar mudanças no grau de justiça. Comparações intragrupo mantêm constante a heterogeneidade não observada entre grupos, pelo menos aquela que é estável no 
tempo - parcela defensavelmente importante, em se tratando de intervalos curtos. Adicionalmente, análises curso a curso controlam também pelas variações entre ofertas.

Pelo AIR, melhorias na posição relativa dos grupos cotistas significariam um aumento no percentual de candidatos elegíveis que seriam aceitos para uma dada oferta de curso. Especificamente, requereria uma queda na $\mathrm{NdeC}$ mais que proporcional a quaisquer reduções na densidade da distribuição das notas na cauda superior.

Do lado da oferta, embora o número total de vagas tenha permanecido praticamente constante entre 2014 e $2017^{17}$, a implementação da LdasC aumentou a quantia de assentos reservados para beneficiários, e reduziu aqueles disputados via ampla concorrência. Tudo o mais constante, esse movimento na oferta tende a majorar a coletividade de candidatos do público-alvo com nota suficiente para aprovação. Em contraste, na demanda os movimentos são incertos.

Substrato teórico para variações na demanda consequentes da LdasC podem ser encontrados tanto na escolha racional quanto nas disposições incorporadas. À medida que a reserva de vagas atenua os riscos percebidos (e.g., de reprovação nos processos seletivos para o ensino superior), tenderia a aquecer a demanda entre o público-alvo das cotas, ceteris paribus.

Dada a visibilidade da LdasC, é razoável supor que essa ação afirmativa desencadeie respostas comportamentais, tanto no que concerne à decisão de prestar o ENEM, quanto ao nível de estorço em preparação ao exame. Tais respostas poderiam se configurar de diferentes maneiras. Primeiro, pode-se pensar em uma reação que afete o contingente de examinados, ou seja, a margem extensiva ${ }^{18}$. A participação no ENEM não parece ser uniformemente distribuída entre grupos raciais; no ENEM 2012, Campos, Storni e Feres Júnior (2014) observam que a presença de pretos nesse exame ( $29 \%$ da população na faixa de 17 a 19 anos) foi superior à de brancos (24\%) e de pardos (17\%). Possíveis razões para esse resultado incluem questões relacionadas à identificação como preto, considerada reduzida, e potenciais impactos de ações afirmativas, as quais possivelmente foram mais efetivas na atração de pretos à universidade, em relação a outras cores / raças, explicam os autores. Esse tipo de resposta poderia mudar o percentual de participantes aprováveis para uma dada oferta, a depender do desempenho dos candidatos adicionais. 
Outro padrão de resposta implica mudanças no nível de preparo da demanda (margem intensiva), as quais poderiam fazer subir o percentual de examinados elegíveis às cotas e com escores competitivos. Um deslocamento para a direita de toda a distribuição de notas no ENEM desse grupo (e.g., analogamente ao que ocorreria diante da implementação de um bônus) seria exemplo desse tipo de alteração. Uma melhoria geral nas competências do grupo poderia originar-se, por exemplo, na agora mais concreta perspectiva de acessar o ensino superior, incentivando escolares da educação básica a investir em seus estudos; este mecanismo provavelmente levaria anos até ser detectável, porque afetaria estudantes ainda jovens demais para a universidade, e porque as percepções quanto aos riscos podem demorar a atualizar-se.

Potencialmente mais dinâmico que o anterior seria o processo decisório que leva estudantes de bom desempenho escolar a almejar a educação terciária e a prestar o ENEM, ampliando a margem extensiva. É plausível que a LdasC tenha encorajado especialmente um perfil que, a despeito de possuir boas chances de aprovação, poderia ter-se autoexcluído da seleção para instituições federais (mais competitivas) e até do próprio ENEM, em linha com os achados de Soares e Júdice (2003), sobre a baixa participação de egressos de escolas estaduais no vestibular da UFMG. Expansão em uma ou ambas as margens seria consistente com a hipótese $a$, declarada a seguir:

a) A LdasC tende a ampliar a participação do público-alvo entre os examinados mais bem preparados do ENEM.

O mesmo racional, alicerçado no aquecimento da demanda, orienta a hipótese $b$, sobre a margem extensiva na procura pela UFMG:

b) A LdasC tende a ampliar a participação do público-alvo entre os candidatos à UFMG.

Ainda que essas interpretações encontrem amparo também na escolha racional, opta-se por balizar as hipóteses $a$ e $b$ nas disposições incorporadas de Bourdieu, menos restritivas em suas assunções, permitindo que os parâmetros de apreciação de cursos variem grupo a grupo. Formulada com base no AIR (Roemer, 1998) e nas considerações sobre movimentos na oferta e na demanda delineados acima, a terceira hipótese postula que: 
c) A LdasC tende a melhorar a posição dos examinados no ENEM elegíveis a M1 em relação àqueles disputando vagas em ampla concorrência (M5). ${ }^{19}$

Por todo o exposto na subseção sobre desigualdades na demanda por cursos, não se poderia modelar o impacto da LdasC sem reconhecer a atratividade e a seletividade de cada curso em relação aos demais, bem como os diferenciais prévios de participação do público-alvo das cotas em seu alunado. Por conseguinte, é possível que o efeito da LdasC pressuposto na hipótese $c$ difira consideravelmente entre cursos. A direção dessas variações é incerta, a priori.

Cursos onde a participação de indivíduos do público-alvo da LdasC seja historicamente maior, acredita-se, tenderiam a ser mais atrativos a esse grupo. Sobre tais carreiras supostamente haveria mais informação disponível no meio de convivência e uma percepção de maiores chances de sucesso.

Paralelamente, se status socioeconômico correlaciona-se negativamente com aversão ao risco, como observaram Martins e Machado (2015), então espera-se que candidatos cotistas sejam mais sensíveis às NdeC (praticadas na última edição do Sisu ou simuladas pelo Sisu antes do fechamento do sistema), evitando as opções de curso onde sua probabilidade (percebida) de admissão seja menor, e favorecendo aquelas menos competitivas, mesmo que estas carreguem valor simbólico ou material mais modesto. Por esse raciocínio, entrar na universidade representa uma conquista em si (provavelmente, de valor figurado ainda maior para o público cotista), ficando em segundo plano questões relativas ao retorno específico da carreira escolhida.

Tudo o mais constante, com a ampliação do percentual de cotas, seria plausível um aumento na competição pelas vagas reservadas dos cursos com menores NdeC. Contudo, por conta dessa intensificação da concorrência, as NdeC propenderiam a alta - o que, possivelmente, minaria a tencionada facilitação do acesso para cotistas. O aumento da competição por uma vaga tornaria a admissão mais difícil para o público-alvo, e desproporcionalmente mais exigente em carreiras de maior participação histórica (e menor prestígio). Em ciclos sucessivos, é razoável imaginar que se instaure um processo de aprendizagem, pelo qual os candidatos se tornam mais conscientes da nova seletividade de cada curso. Possivelmente, passariam a considerar opções menos convencionais para seu grupo, no intuito de dilatar as chances de 
aprovação. Entretanto, o ritmo desse aprendizado é desconhecido, podendo ocorrer imediatamente, durante as simulações do Sisu, ou entre processos seletivos. Ademais, a intensidade da preferência em favor de cursos mais "familiares" e o grau de sensibilidade às NdeC são igualmente ignorados. Destarte, considera-se adequada uma hipótese não direcional - i.e., que não preveja quais cursos mostrariam maior (ou menor) efetividade da LdasC; a quarta e última hipótese lê-se assim:

d) Os efeitos da LdasC previstos na hipótese $c$ ocorrem em intensidade variável, conforme características dos cursos ofertados.

As hipóteses especificadas atentam tanto para potenciais mecanismos, no processo de alocação de vagas, afetados pela LdasC ( $a$ e $b$, referentes à primeira pergunta de pesquisa), quanto para as dimensões de manifestação de efeitos sobre a desigualdade no acesso à universidade ( $c$ e $d$, concernentes à segunda pergunta de pesquisa). A próxima seção descreve o desenho do estudo e os dados reunidos para exame dessas hipóteses.

\section{DESENHO DA PESQUISA}

Esta seção apresenta os dados aplicados no estudo e o desenho da pesquisa, com foco na estratégia de identificação de efeitos. Detalhes sobre as estimações usadas em cada teste de hipótese são providos na quarta seção, que introduz as análises.

\section{DADOS}

Todos os dados analisados são de acesso público, e advêm de quatro fontes. Primeiro, há aqueles referentes aos processos seletivos para ingresso nos cursos presenciais oferecidos nos campi da UFMG em Belo Horizonte $^{20}$ e com recrutamento baseado exclusivamente no ENEM ${ }^{21}$, nos anos de 2014 a 2017. Os dados da UFMG correspondem aos valores das notas (médias das cinco provas do ENEM $^{22}$ ) mínimas para ingresso em cada modalidade (ampla concorrência e reservas), após a última chamada para matrícula, extraídos da web page do Departamento de Registro e Controle Acadêmico (DRCA/UFMG) ${ }^{23}$, e informações sobre vagas e candidatos, disponibilizadas parte pela Pró-Reitoria de Graduação (Prograd/UFMG), parte pelo DRCA/UFMG via Lei de Acesso à Informação (lei federal n. 12.527, de 18 de novembro de 2011). 
Algumas análises incluem atributos das carreiras disponibilizados por Martins e Machado (2015), entre os quais: rendimento esperado (dos 25 aos 65 anos, em reais de 2010 por hora de trabalho); percentual de ocupação dos indivíduos; percentual de negros e de mulheres entre os graduados (com base no Censo Demográfico 2010); e renda domiciliar per capita (durante a graduação, em reais de 2010, excetuando-se a renda do próprio indivíduo).

A terceira fonte são microdados dos Censos Escolares anuais do Inep, de 2011 a 2015, com informações sobre concluintes do ensino médio. Os microdados das edições 2011 a 2015 do ENEM correspondem à quarta fonte, e contêm a sociodemografia dos inscritos e sua trajetória escolar. Para o ENEM e os Censos Escolares, são considerados somente os indivíduos residentes na Região Metropolitana de Belo Horizonte $(\mathrm{RMBH})$, incluindo o chamado Colar Metropolitano, e totalizando 50 (6\%) dos 853 municípios mineiros. Mais de $75 \%$ dos candidatos à UFMG em todos os processos seletivos de 2011 a 2015 residiam na capital ou na Grande BH (Takahashi, Caminhas, Pena, 2015). O banco de dados composto a partir das quatro fontes estrutura-se no formato dados de corte transversal empilhados.

A natureza dos dados disponíveis impôs restrições ao desenho da pesquisa. Em particular, inviabiliza a identificação dos indivíduos que não teriam sido aprovados na ausência da LdasC (displacing applicants, na linguagem de Francis e Tannuri-Pianto, 2012), e daqueles que deixaram de ser aprovados em razão das cotas (displaced applicants). Também, não se pode determinar quais examinados no ENEM se candidataram a vagas na UFMG, nem para qual oferta, se assim o fizeram.

Outrossim, variações nos formatos dos processos seletivos levam a diversas incompatibilidades, como explicam Nogueira et al. (2017). Desde 2012, a UFMG adotou processos seletivos tanto anuais, alocando vagas para entrada no primeiro e segundo semestres (em 2012, 2013, 2016 e 2017), quanto semestrais (2014 e 2015); com prova própria na segunda fase (em 2012 e 2013), e em fase única via Sisu, considerando apenas o ENEM como teste de entrada (desde 2014); tendo um sistema próprio de bônus sociorracial como ação afirmativa no acesso (em 2012), e reservando vagas pela LdasC (desde 2013). Há duas janelas de comparabilidade, em que as formas de seleção se mantiveram estáveis: uma nos processos seletivos de 2014-2015, outra a partir de 2016. As

DADOS - Revista de Ciências Sociais, Rio de Janeiro, vol. 61, no 2, 2018 
análises adiante focam a primeira dessas janelas, onde houve variação no percentual de vagas reservadas.

\section{Estratégia de identificação: experimento natural e fronteira de pareamento}

As cotas foram implementadas conforme um padrão escalonado definido pela própria lei: ao menos $12,5 \%, 25,0 \%, 37,5 \%$ e $50,0 \%$ das vagas de cada curso e turno de instituições de ensino superior federais tiveram de ser destinadas aos cotistas nos anos de 2013, 2014, 2015 e 2016, respectivamente. Na UFMG, a reserva ocorreu exatamente na medida dos mínimos estipulados.

A implantação gradual da LdasC torna a expansão da reserva "como se" aleatória ("as if" random) entre coortes de concluintes do ensino médio com uma certa idade, possibilitando um experimento natural com uma espécie de pré-teste (observações anteriores à expansão a reserva, embora não referentes aos mesmos indivíduos observados no pós-teste) e um grupo de comparação reverso (os concorrentes na M5, para quem reduziram-se os assentos disponíveis) ${ }^{24}$. Dunning (2008:282-283) descreve experimento natural e qualifica sua característica definidora, a atribuição "como se" aleatória ao tratamento:

Because the manipulation of treatment variables is not generally under the control of the analyst, natural experiments are, in fact, observational studies. However, unlike other nonexperimental approaches, a researcher exploiting a natural experiment can make a credible claim that the assignment of the nonexperimental subjects to treatment and control conditions is "as if" random. Outcomes are compared across treatment and control groups, and both a priori reasoning and empirical evidence are used to validate the assertion of randomization.

Para concluintes do ensino médio em 2014 com 17 anos em 31 de dezembro daquele ano (a idade de maior incidência nesse perfil entre tomadores do ENEM), prestar o ENEM em 2014 e concorrer a uma vaga no ensino superior com início no primeiro semestre de 2015 (quando a reserva de vagas na UFMG era de $37,5 \%$ ) e não no primeiro semestre de 2014 (com reserva de 25,0\%), é uma condição decorrente do seu ano de nascimento, um evento completamente alheio ao controle do indivíduo e aleatório em natureza. Essa comparabilidade presumida entre as coortes, exceto pela intensidade do tratamento, é o elemento central da estratégia de identificação dos efeitos da reserva de vagas. 
Do lado da oferta, mudanças significativas no cardápio de cursos e instituições disponíveis poderiam influenciar a demanda pelo ensino superior (em geral e na UFMG em particular), e comprometer a validade interna das estimativas de efeito. Essa possibilidade, ainda que plausível, não é provável. Dados das sinopses Estatísticas da Educação Superior 2014 e 2015, do Inep, revelam pouca variação no número de cursos de graduação presencial ofertados em Minas Gerais.

Admite-se, todavia, a natureza localizada do estudo. O foco em um perfil específico de examinados (concluintes do ensino médio com 17 anos) fortalece a validade interna, porém restringe a possibilidade de generalização dos resultados, os quais poderiam ser diversos para outras faixas etárias e condições de escolarização.

Enquanto a atribuição ao tratamento aproximou-se de um processo aleatório, a amostra de examinados no ENEM não é aleatória. De um lado, foi preciso excluir examinados para os quais a informação sobre elegibilidade às quotas não estava completa. De outro, e mais importante, o ENEM é um exame voluntário. Estudantes se autosselecionam ao prestar o ENEM e, da mesma forma, ao concorrer à UFMG. Assim, é importante mitigar potenciais ameaças à comparabilidade entre as coortes, o que é feito via fronteira de pareamento, abordagem apresentada adiante.

Ademais, nos microdados do ENEM 2014, valores faltantes para a dependência administrativa do ensino médio comprometeram a identificação da elegibilidade às modalidades de entrada, levando a uma redução brusca da amostra de trabalho. Dos mais de 7,1 milhões de inscritos no ENEM 2013, 17.919 indivíduos atendiam aos requisitos estabelecidos ${ }^{25}$. Entre os 8,7 milhões de inscritos no ENEM 2014, apenas 6.222 preenchiam tais condições, um contingente equivalente a $34,72 \%$ da amostra de 2013. A Tabela 1 especifica a composição, por elegibilidade às modalidades de entrada, das coortes do ENEM 2011 a 2015 (sempre considerando o subconjunto de inscritos que atendem aos requisitos para pertencimento à amostra de trabalho). Observa-se uma elevação da participação da M1 (que reúne o maior número de condições "desfavorecidas") na amostra de 2014 (um aumento de 10,4 pontos percentuais em relação a 2013), enquanto a M5 (ampla concorrência) perde 13,7 pontos.

Uma técnica de pareamento comumente aplicada é o pareamento por escore de propensão (propensity score matching-PSM), inicialmente de-

DADOS - Revista de Ciências Sociais, Rio de Janeiro, vol. 61, n’ 2, 2018 
Tabela 1

Examinados do ENEM residentes na RMBH, com informação sobre elegibilidade às modalidades de entrada, concluintes do ensino médio com 17 anos (2011-2015)*

\begin{tabular}{lrrrrrrrrr}
\hline & \multicolumn{4}{c}{ Participação (em \%) } & \multicolumn{3}{c}{ Variação (em pontos percentuais) } \\
\cline { 2 - 10 } Modalidade & $\mathbf{2 0 1 1}$ & $\mathbf{2 0 1 2}$ & $\mathbf{2 0 1 3}$ & $\mathbf{2 0 1 4}$ & $\mathbf{2 0 1 5}$ & $\mathbf{2 0 1 1 - 2 0 1 2}$ & $\mathbf{2 0 1 2 - 2 0 1 3}$ & $\mathbf{2 0 1 3}-\mathbf{2 0 1 4} \mathbf{2 0 1 3 - 2 0 1 5}$ \\
\hline 1 & 51,8 & 48,0 & 48,6 & 59,0 & 49,7 & $-3,8$ & 0,7 & 10,4 & 1,0 \\
2 & 24,2 & 21,5 & 21,2 & 26,2 & 19,1 & $-2,8$ & $-0,2$ & 5,0 & $-2,2$ \\
3 & 0,3 & 3,3 & 3,4 & 2,6 & 4,4 & 3,0 & 0,2 & $-0,8$ & 1,0 \\
4 & 0,3 & 2,3 & 2,4 & 1,6 & 2,3 & 1,9 & 0,1 & $-0,8$ & 0,0 \\
5 & 23,4 & 25,0 & 24,3 & 10,6 & 24,6 & 1,6 & $-0,8$ & $-13,7$ & 0,3 \\
Todas & 100,0 & 100,0 & 100,0 & 100,0 & 100,0 & - & - & - & - \\
\hline Observações & 16.134 & 16.755 & 17.919 & 6.222 & 17.080 & - & - & - & - \\
\hline
\end{tabular}

Nota: *Outras restrições se aplicam (vide nota 25). A coorte 2011 do ENEM não foi afetada pela LdasC, e aparece aqui apenas para fins de comparação histórica.

Fonte: Elaboração própria, com base nos microdados do ENEM 2011-2015

senvolvida por Rosenbaum e Rubin (1983). PSM identifica um subgrupo de comparação estatisticamente equivalente ao de tratamento; para tanto, modela a probabilidade de uma unidade estar no grupo de tratamento com base em características não afetadas pelo mesmo. Unidades do grupo de tratamento são então pareadas com unidades do grupo de comparação, com base em suas probabilidades estimadas de participação no grupo de tratamento - propensity scores.

Embora amplamente empregado, o PSM vem enfrentado duras críticas. As abordagens típicas de pareamento fixam o tamanho da amostra pareada e maximizam o equilíbrio entre os grupos (balance), ou vice-versa. Qualquer desses procedimentos tende a conduzir a soluções subótimas, explicam King, Lucas e Nielsen (2017): se o subconjunto identificado pelo pareamento for muito reduzido (para garantir maior comparabilidade entre grupos), o ganho em acurácia (i.e., validade interna ou ausência de viés) será contrabalançado por um alto nível de variância (i.e., imprecisão) nas estimativas. Da mesma forma, em uma grande amostra pareada, a redução da variância será acompanhada por provável desequilíbrio entre os grupos - e consequente viés de dependência do modelo (model dependence bias), implicando alta sensibilidade das estimativas às especificações do modelo de regressão utilizado. Pesquisadores acabam ajustando, local e iterativamente, seu procedimento de matching e checando sucessivamente o equilíbrio, sem perspectiva panorâmica das possibilidades de ajuste. 
A chamada balance-sample size frontier, ou simplesmente matching frontier, desenvolvida por King, Lucas e Nielsen (2017), propõe-se a resolver o problema das soluções subótimas de pareamento. Para cada tamanho de amostra, a fronteira apresenta a opção de matching com o máximo equilíbrio possível. Ao invés de implementar ajustes repetidamente, o pesquisador pode selecionar na fronteira uma solução de pareamento e conduzir sua análise em um passo apenas.

Neste estudo, a fronteira de pareamento foi aplicada no exame das hipóteses $c$ e $d$, considerando uma série de 25 variáveis de pareamento, e abrangendo as seguintes categorias de atributos individuais, todos extraídos dos microdados do ENEM: i) variáveis tocantes à trajetória educacional no ensino médio e fundamental (e.g., dependência administrativa); ii) variáveis relativas à renda familiar, educação parental e acesso a diversos bens e serviços em casa (e.g., lavadora, internet); iii) variáveis relativas à cor/ raça; e iv) controles como área de moradia (urbana ou rural), sexo, experiência no mercado de trabalho e opção de língua estrangeira (inglês ou espanhol).

A próxima seção examina as quatro hipóteses aventadas, começando por aquelas relativas a efeitos da LdasC sobre a demanda pela UFMG. Após, procede à avaliação dos efeitos da reserva sobre a posição relativa dos grupos, e conclui com considerações sobre padrões de impacto na avaliação curso a curso.

\section{ANÁLISES}

Para testar a hipótese $a$, de que a LdasC tende a ampliar a participação do público-alvo entre os examinados mais bem preparados do ENEM, cabe observar a composição destes. A Tabela 2 exibe o percentual de examinados pertencentes ao decil superior de notas, por modalidade para a qual são elegíveis (segundo suas respostas ao questionário socioeconômico do ENEM), considerando as edições 2011 a 2015 do teste e as restrições à amostra de trabalho, explicitadas na seção anterior.

Em 2013, primeira edição do ENEM completamente realizada após a LdasC, M1, M3 e M4 tiveram sua presença no primeiro decil de notas aumentada em 7, 33 e 5\%, respectivamente, enquanto M2 encolheu $29 \%$. Na comparação 2013-2015, as participações de M3 e M4 declinaram por volta de $20 \%$, enquanto M1 e M2 mantiveram-se estáveis.

DADOS - Revista de Ciências Sociais, Rio de Janeiro, vol. 61, nº 2, 2018 
Tabela 2

Examinados do ENEM residentes na RMBH, com informação sobre elegibilidade às modalidades de entrada, concluintes do ensino médio com 17 anos, no decil superior de nota (2011-2015)*

\begin{tabular}{lrrrrrrrrrr}
\hline & \multicolumn{4}{c}{ Participação (em \%) } & \multicolumn{3}{c}{ Variação (em pontos percentuais) } \\
\hline Modalidade & $\mathbf{2 0 1 1}$ & $\mathbf{2 0 1 2}$ & $\mathbf{2 0 1 3}$ & $\mathbf{2 0 1 4}$ & $\mathbf{2 0 1 5}$ & $\mathbf{2 0 1 1 - 2 0 1 2}$ & $\mathbf{2 0 1 2 - 2 0 1 3}$ & $\mathbf{2 0 1 3 - 2 0 1 4}$ & $\mathbf{2 0 1 3 - 2 0 1 5}$ \\
\hline 1 & 12,3 & 7,0 & 7,5 & 31,8 & 7,6 & $-5,3$ & 0,5 & 24,3 & 0,1 \\
2 & 9,5 & 5,9 & 4,2 & 18,6 & 4,2 & $-3,6$ & $-1,7$ & 14,4 & 0,0 \\
3 & 0,5 & 3,3 & 4,4 & 5,0 & 3,6 & 2,8 & 1,1 & 0,6 & $-0,8$ \\
4 & 0,9 & 4,2 & 4,4 & 2,9 & 3,3 & 3,3 & 0,2 & $-1,5$ & $-1,1$ \\
5 & 76,8 & 79,6 & 79,5 & 41,6 & 81,3 & 2,8 & $-0,1$ & $-37,9$ & 1,8 \\
Todas & 100,0 & 100,0 & 100,0 & 100,0 & 100,0 & - & - & - & - \\
\hline \multicolumn{2}{l}{ Observações } & 1.613 & 1.674 & 1.791 & 622 & 1.708 & - & - & - & -
\end{tabular}

Nota: * Outras restrições se aplicam (vide nota 25). A coorte 2011 do ENEM não foi afetada pela LdasC, e aparece aqui apenas para fins de comparação histórica.

Fonte: Elaboração própria, com base nos microdados do ENEM 2011-2015

Resultados de regressões multinomiais são apresentados na Tabela 3. Uma extensão do modelo logit binário, essas regressões são capazes de tratar variáveis dependentes nominais, representativas de uma classificação não ordenada com pelo menos três categorias (Long, Freese, 2001) - aqui, as modalidades de entrada. É estimado um conjunto de $J$-1 equações, em que $J$ corresponde ao número de categorias (cinco, neste caso $)^{26}$. A variável dependente é o logaritmo da razão de risco relativo (relative risk ratio); esta consiste na divisão de duas probabilidades: a probabilidade de a observação pertencer a uma modalidade $\left(\pi_{i j}\right)$ e a probabilidade de pertencer à modalidade de referência $\left(\pi_{i J}\right)$, como expressa a equação I; M5 é a categoria de referência. A constante $\alpha$ e uma série de coeficientes de inclinação $\beta$ são os parâmetros estimados. O vetor $X$ é formado por dummies indicando a edição do ENEM da qual uma certa observação advém, enquanto $\varepsilon$ é o erro estocástico; $\varepsilon^{\hat{\beta}}$ é interpretado como um efeito multiplicativo na razão de risco relativo.

(1) $\log \left(\frac{\pi_{i j}}{\pi_{i j}}\right)=\alpha_{j}+\beta_{j} * X_{i}+\varepsilon_{i j}$

Em relação a 2012, ano-base de comparação, participantes do ENEM 2013 e 2015 pertencentes ao decil superior de notas não eram estatisticamente mais prováveis de se qualificarem para a reserva de vagas (M1 a M4). Ao contrário, os únicos coeficientes estatisticamente signi- 
ficantes, referentes a M2, sugerem que esse grupo era menos prevalente nos anos de 2013 e 2015 quando comparados a 2012, como mostra o risco relativo inferior à unidade. A retirada do ano de 2014 da amostra não altera as estimativas ${ }^{27}$.

Tabela 3

Razões de risco relativo estimadas via modelo logit multinomial, com elegibilidade às modalidades de entrada como variável dependente, no decil superior de nota no ENEM dos examinados residentes na RMBH (2011-2015)

\begin{tabular}{lccccc}
\hline Variável & $\begin{array}{c}\text { Modali- } \\
\text { dade 1 }\end{array}$ & $\begin{array}{c}\text { Modali- } \\
\text { dade 2 }\end{array}$ & $\begin{array}{c}\text { Modali- } \\
\text { dade 3 }\end{array}$ & $\begin{array}{c}\text { Modali- } \\
\text { dade 4 }\end{array}$ & $\begin{array}{c}\text { Teste Wald rejeita, a } \alpha=\mathbf{5 \% ,} \\
\text { Ho: Todos os } \beta \mathbf{s}=\mathbf{0} ?\end{array}$ \\
\hline ENEM 2011 & $1,804 * * *$ & $1,689 * * *$ & $0,156 * * *$ & $0,212 * * *$ & Sim \\
ENEM 2012 (base) & - & - & - & - & - \\
ENEM 2013 & 1,071 & $0,726 * *$ & 1,327 & 1,042 & Não \\
ENEM 2014 & $8,630 * * *$ & $6,087^{* * *}$ & $2,899 * * *$ & 1,304 & Sim \\
ENEM 2015 & 1,048 & $0,705 * *$ & 1,081 & 0,756 & Não \\
Constante & $0,089 * * *$ & $0,074 * * *$ & $0,041 * * *$ & $0,053 * * *$ & - \\
Observações & 7.408 & 7.408 & 7.408 & 7.408 & - \\
\hline
\end{tabular}

Notas: ${ }^{\dagger}$ Outras restrições se aplicam (vide nota 25 ). ${ }^{* * *} \mathrm{p}<0,01 ;{ }^{* *} \mathrm{p}<0,05 ;{ }^{*} \mathrm{p}<0,10$. Pseudo $\mathrm{R}^{2}=0,05$. Fonte: Elaboração própria, com base nos microdados do ENEM 2011-2015.

Essa aparente constância na composição do decil superior é melhor compreendida à luz da demanda potencial pela educação terciária. Estimações multinomiais similares a I foram aplicadas aos microdados dos Censos Escolares de 2011 a 2015, abarcando concluintes do ensino médio com 17 anos no ano de referência do censo e formando um contingente de 76.825 estudantes moradores da RMBH. A indisponibilidade de dados impôs algumas diferenças em relação às análises baseadas no ENEM. Primeiramente, os censos não informam sobre a dependência administrativa das escolas frequentadas ao longo do ensino médio. Por isso, foram considerados elegíveis a M5 todos os estudantes concluintes do ensino médio (terceiro ou quarto ano) em escolas privadas. Os demais, foram tidos como elegíveis a M1 ou M3, de um lado, M2 ou M4, de outro. Os censos não perguntam sobre a renda familiar, portanto não é possível categorizar estudantes conforme esse atributo. Ainda, os censos não capturam a dimensão preparo acadêmico, inviabilizando análises restritas a certos quantis segundo essa dimensão.

Apura-se que potenciais cotistas foram menos presentes entre os concluintes do ensino médio nos anos de 2013 e 2015, estes em relação a 2012, em particular no que concerne a M1 e M3, como indicam as Tabe-

DADOS - Revista de Ciências Sociais, Rio de Janeiro, vol. 61, nº 2, 2018 
las A1 e A2, do Apêndice. A estabilidade na participação de M1 e M3 exibida na Tabela 3, mesmo tendo esses grupos, em conjunto, encolhido entre concluintes do ensino médio, sugere que, se houve algum efeito da LdasC, este foi no sentido de evitar uma queda do público-alvo entre os examinados com melhores notas. Contudo, não se sabe como a redução dos concluintes do ensino médio se distribuiu entre os níveis de preparo acadêmico. Em função disso, opta-se aqui por uma interpretação mais conservadora, pela qual não se detecta evidência sustentando a hipótese $a$.

A seu turno, a hipótese $b$, a qual prognostica uma expansão da participação do público-alvo da LdasC entre os candidatos a uma vaga na UFMG, encontra amparo empírico. Nos processos seletivos de 2014 e 2015 (primeiros semestres) ${ }^{28}, 2016$ e 2017, fica patente a ampliação do contingente pleiteando vagas reservadas, que passou a ser a maioria dos concorrentes em 2016 (Tabela 4).

Tabela 4

Candidatos a ofertas de graduação presencial nos campi da UFMG de Belo Horizonte* $^{*}$ 2014-2017)**

\begin{tabular}{lrrrrrrr}
\hline & \multicolumn{3}{c}{ Participação (em \%) } & \multicolumn{3}{c}{ Variação (em pontos percentuais) } \\
\cline { 2 - 8 } Modalidade & $\mathbf{2 0 1 4}$ & $\mathbf{2 0 1 5}$ & $\mathbf{2 0 1 6}$ & $\mathbf{2 0 1 7}$ & $\mathbf{2 0 1 4 - 2 0 1 5}$ & $\mathbf{2 0 1 5 - 2 0 1 6}$ & $\mathbf{2 0 1 6 - 2 0 1 7}$ \\
\hline 1 a 4 (Reserva) & 36,8 & 45,8 & 57,1 & 59,3 & 9,0 & 11,3 & 2,2 \\
5 & 63,2 & 54,2 & 42,9 & 40,7 & $-9,0$ & $-11,3$ & $-2,2$ \\
Todas & 100,0 & 100,0 & 100,0 & 100,0 & - & - & - \\
\hline Observações & 172.400 & 170.924 & 189.263 & 166.044 & - & - & - \\
\hline
\end{tabular}

Notas: * Considera inscrições para a primeira ou a segunda opção de curso, apenas para as 83 ofertas cujo processo seletivo baseia-se exclusivamente no ENEM. ${ }^{* *}$ Em 2014 e 2015, considera apenas o processo seletivo para ingresso no primeiro semestre.

Fonte: Elaboração própria, com base nos dados das candidaturas à UFMG (2014-2017).

A análise ao nível das ofertas de curso de graduação (equação II), apoiada numa regressão com efeitos fixos (Stock, Watson, 2003), confirma essa evidência. As ofertas variam em função do curso $c$ (e.g., Ciências Biológicas, Direito), da formação $f$ (e.g., bacharelado, licenciatura), do turno $t$ (e.g., matutino, noturno) e do processo seletivo $p$ (2014 ou 2015).

(II) $\quad$ Candidatos $_{c f t m p}=\alpha+\beta^{*}$ Reserva $_{m}+\gamma^{*} A n o_{p}+\delta^{*}$ Reserva $_{m}{ }^{*} A n o_{p}+o_{c f t}+\varepsilon_{c f t m p}$

Tomando-se o número de candidatos como variável dependente, e tendo como variáveis explicativas uma dummy indicando se a concorrên- 
cia em questão é por vagas reservadas, dummies para oferta (efeitos fixos de oferta, representados por o), dummies indicando ano (efeitos fixos de tempo) e interações destas com a dummy para reserva, obtêm-se coeficientes estatisticamente significantes e positivos para as interações (Tabela 5). Tal resultado aponta que o número de candidatos por oferta tendeu a se elevar na disputa por assentos reservados, como previa a hipótese $b$.

Pela hipótese $c$, espera-se que a LdasC melhore a posição dos examinados elegíveis a M1 (modalidade que acumula maior número de condições "desfavorecidas") em relação à posição dos examinados que tiveram alguma passagem pelo ensino médio privado e, portanto, não se qualificam às vagas reservadas. Tal expectativa é testada a partir de uma série de regressões. Em todas elas, a variável dependente corresponde à diferença entre a nota média ${ }^{29}$ obtida pelo examinado no ENEM e a NdeC (nota mínima para admissão, após a última convocação), considerando M1, M5 e as diferentes ofertas de cursos. Cada indivíduo $i$ é localizado no esquema de cotas conforme a categoria para a qual se qualifica ${ }^{30}$. A NdeC para cada modalidade $m$, em cada processo seletivo $p$ é então contrastada com a nota média obtida por $i$; resultados positivos ou nulos indicam que a pessoa em questão seria aprovada para a oferta específica. Como na análise anterior, as ofertas variam em função do curso $c$, da formação $f$, do turno $t$ e do processo seletivo $p$. Assume-se que os candidatos a uma vaga na UFMG são tomadores, e não formadores da NdeC - i.e., as notas mínimas para admissão em diferentes ofertas são consideradas dadas para os participantes do processo seletivo.

Das 71 ofertas para graduação com início no primeiro semestre de 2014 e 2015, 48 (listadas na Tabela A3, do Apêndice) são consideras nas análises adiante; estas ofertas referem-se a cursos para os quais atributos como rendimentos esperados, proporção dos graduados que estão trabalhando, e proporção de mulheres entre graduados estão disponíveis em Martins e Machado (2015). Regressões são calculadas separadamente para cada combinação de oferta e modalidade (M1 ou M5). Essas estimações concernem a dois processos seletivos, e a duas edições do ENEM (2013 e 2014, respectivamente). São aplicadas duas especificações, $I I I$ e $I V$, a primeira sem e a segunda com controles. Dessa forma, têm-se 192 regressões ( 48 ofertas $* 2$ modalidades * 2 especificações).

DADOS - Revista de Ciências Sociais, Rio de Janeiro, vol. 61, n’ 2, 2018 
Ana Karruz

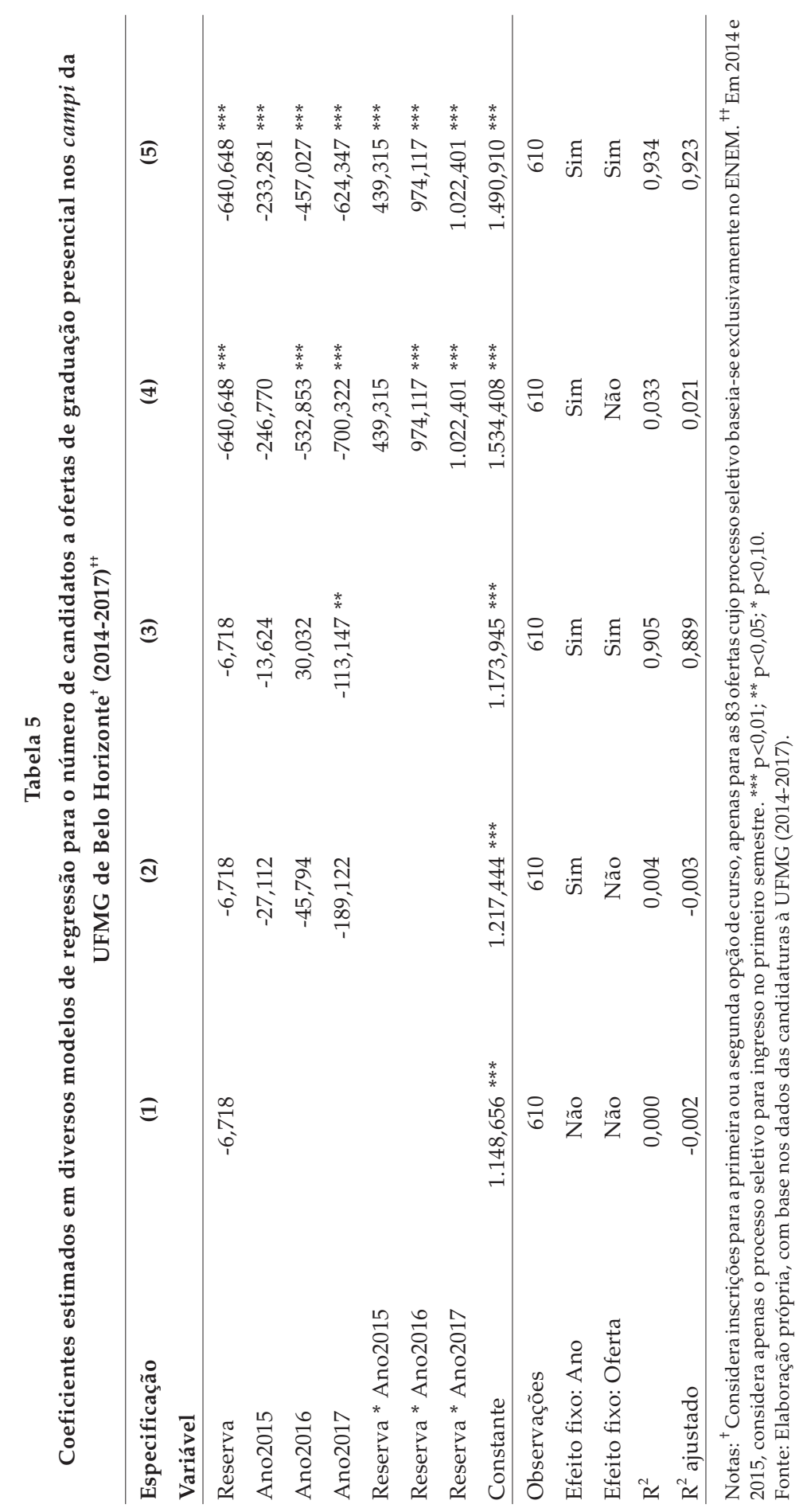

432 DADOS - Revista de Ciências Sociais, Rio de Janeiro, vol. 61, no 2, 2018 


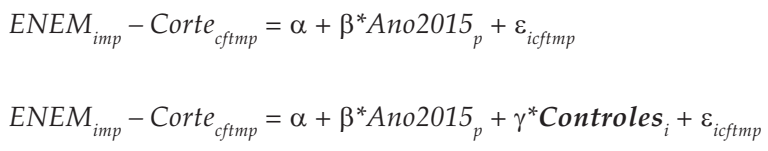

A unidade de observação é indivíduo-curso-formação-turno-modalidade-processo (i-c-f-t-m-p). Ano2015 é uma variável binária que identifica o processo seletivo (2014 ou 2015). O vetor Controles contém atributos individuais, quais sejam, o número de pessoas morando na residência e dummies para: intenção de se candidatar à educação superior pública ${ }^{31}$; cor/ raça preta; concluindo o ensino médio em escola federal; concluindo o ensino médio em escola municipal; renda familiar per capita até 1,5 salário mínimo; mãe sem ensino médio completo; e pai sem ensino médio completo. O erro aleatório é representado por $\varepsilon$.

Os efeitos estimados, correspondentes a $\hat{\beta}$, representam o deslocamento ("empurrão") médio que a LdasC causa na posição do grupo (modalidade) em relação à NdeC. Dito de outra forma, espelham a variação média na variável dependente entre os processos seletivos de 2014 e 2015, sendo tal variação atribuível à LdasC. Todas as regressões são calculadas em subamostras contendo entre 146 e 176 observações - observações estas que minimizam o desequilíbrio (imbalance) entre as coortes do ENEM 2013 e 2014; as subamostras foram definidas via fronteiras de pareamento ${ }^{32}$. Optou-se por reter um número reduzido de observações, pois desta forma espera-se remover em grande medida potenciais vieses sobre os efeitos apurados. A Figura A1, do Apêndice, apresenta as fronteiras de pareamento e as estimativas de efeito ao longo delas, para a oferta Administração (bacharelado noturno); as fronteiras das demais ofertas (não mostradas) seguem um padrão semelhante.

Dos 96 coeficientes estimados $(\hat{\beta})$ via $I V, 54$ são estatisticamente significantes a 5\%, sendo 26 na M1 e 28 na M5. A Tabela 6 exemplifica a estimação dos parâmetros, considerando o bacharelado noturno em Administração. Para participantes da seleção de 2015 elegíveis a M1, a diferença média entre a nota obtida pelo candidato e a NdeC ficou ao redor de 17 pontos maior em relação a examinados comparáveis do ano anterior, ceteris paribus, porém apenas marginalmente significante. Já os pretendentes a vagas de livre concorrência viram sua posição em relação à NdeC deteriorar-se, todavia não de maneira estatisticamente significante, segundo a especificação com controles. 


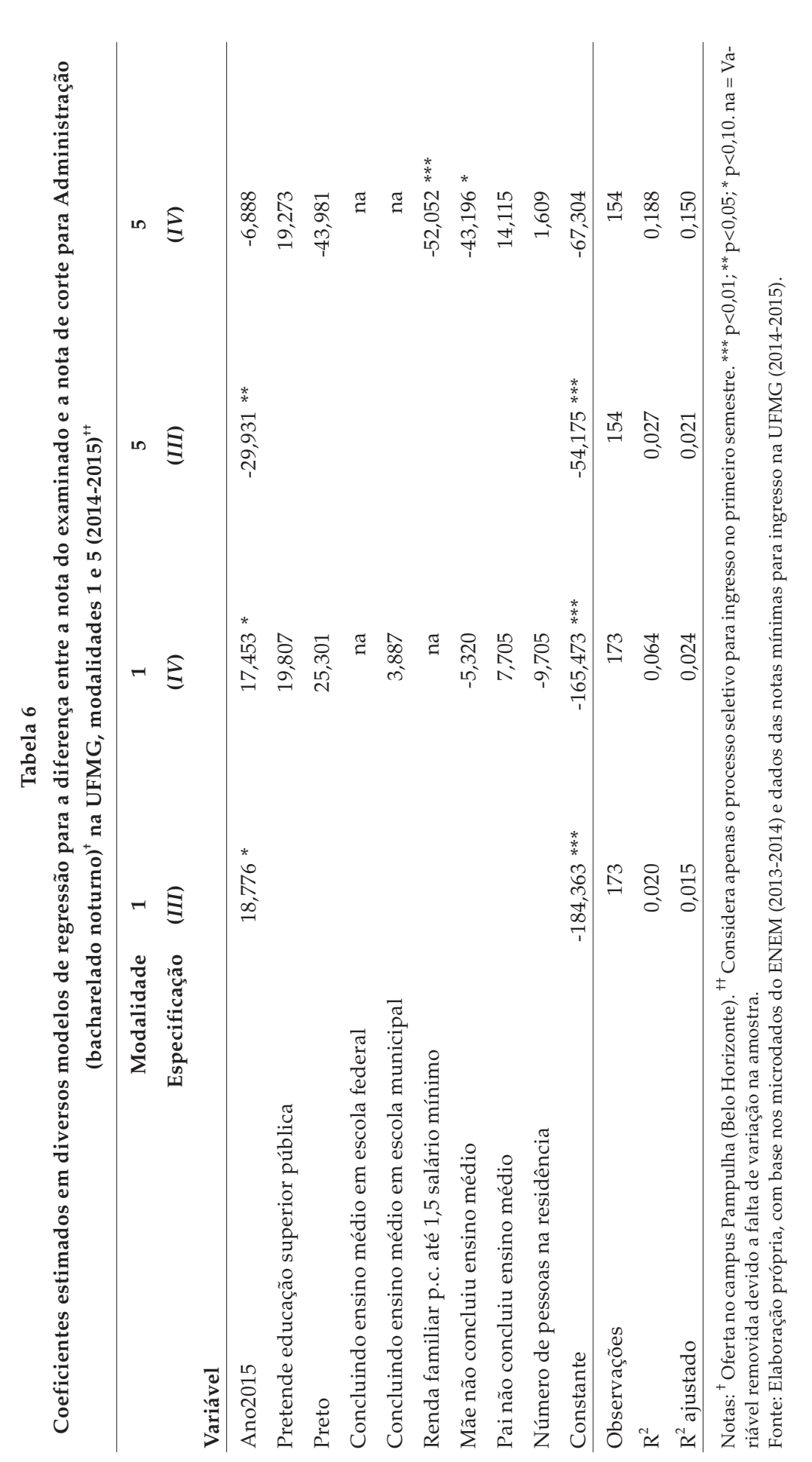

434 DADOS - Revista de Ciências Sociais, Rio de Janeiro, vol. 61, n² 2, 2018 
Mas, quão relevantes são esses "empurrões"? Para analisar os efeitos estimados à luz de sua importância, adotou-se uma rotina de três passos, para cada uma das 48 ofertas consideradas. Primeiro, com base nas notas do ENEM 2013 ( $n=17.919$ ), são calculados os quantis correspondentes à NdeC de M1 e M5 para ingresso em 2014. Dessa forma, obtém-se a desigualdade inicial, entendida como a diferença entre o quantil necessário para aprovação em M1 e aquele requerido na M5. A Tabela A4 (Apêndice) retrata essa medida, e revela que a desigualdade inicial favorece M5 em todas as ofertas. Pedagogia licenciatura noturno é a oferta com maior desigualdade inicial: em M1, aprovação exige desempenho igual ou superior ao de $94,2 \%$ dos examinados; em M5, basta superar $45,8 \%$ deles - uma distância de 48,4 percentis. A menor desigualdade inicial foi observada em Medicina, curso com exigência altíssima também na livre concorrência, aprovando apenas os 0,7\% mais preparados nesse grupo.

O segundo passo foi calcular a nota simulada, qual seja, a nota do indivíduo $i$ no ENEM 2013, adicionada do deslocamento, estimado nas regressões com controles, para aquela respectiva oferta e modalidade. Coeficientes que não mostraram significância estatística a $5 \%$ foram substituídos por zero, quedando a nota simulada igual àquela alcançada no ENEM 2013. A seguir, identificou-se o quantil referente a cada nota simulada. A desigualdade simulada $(\Delta)$, posterior à LdasC, corresponde à diferença entre o quantil (simulado) necessário para aprovação em M1 e aquele simulado para M5. A desigualdade simulada foi menor que a inicial para 37 ofertas, igual para 10 e maior para uma (Engenharia Aeroespacial). Para duas ofertas, Aquacultura e Engenharia Química, a desigualdade inverteu-se, sugerindo que a LdasC conduziu os candidatos de M1 a uma posição mais vantajosa que a daqueles disputando na ampla concorrência (Tabela A4).

No terceiro e último passo, calculou-se a variação percentual da desigualdade $(\Delta \%)$. Para tanto, subtraiu-se a desigualdade inicial da final (simulada), dividindo-se essa diferença pela desigualdade inicial; o quociente foi, então, multiplicado por 100, como em $V$, abaixo.

(V) $\Delta_{c f t, 2014-2015}=100 *\left(\right.$ desigualdade simulada $a_{c f t, 2015}-$ desigualdade $\left._{c f t, 2014}\right) /$

(desigualdade ${ }_{c f t, 2014}$ )

em que:

desigualdade simulada ${ }_{2015}=$ quantil $_{M 1,2015}-$ quantil $_{M 5,2015}$

desigualdade $_{2014}=$ quantil $_{M 1,2014}-$ quantil $_{M 5,2014}$

quantil = quantil da NdeC (observado em 2014 e simulado em 2015)

DADOS - Revista de Ciências Sociais, Rio de Janeiro, vol. 61, no 2, 2018 
Em média, a variação percentual da desigualdade $(\Delta \%)$ foi de $-43,5 \%$, favorecendo M1. A evidência reunida provê suporte à hipótese $c$, indicando que a LdasC melhorou a posição dos elegíveis a M1 em relação aos candidatos da livre concorrência.

Para averiguar a hipótese $d$, sobre a existência de efeitos da LdasC que sejam sistematicamente diferentes entre ofertas, computaram-se correlações entre a variação percentual da desigualdade $(\Delta \%)$ e características da oferta - especificamente, número de candidatos por vaga (todas as modalidades) e NdeC, além de cinco atributos dos cursos, extraídos de Martins e Machado (2015), a saber: renda domiciliar per capita durante a graduação; rendimento esperado por hora de trabalho (dos 25 aos 65 anos); percentual de graduados ocupados; percentual de graduados pretos ou pardos; percentual de graduados mulheres (Tabela A5, do Apêndice).

As correlações estimadas apresentam tímida magnitude (até $|0,17|$ ), à exceção da correlação com a relação candidato/vaga, que é de 0,43 , a única estatisticamente diferente de zero a $5 \%$ de significância. Testes $t$ de diferença entre médias (não mostrados) indicam que a variação percentual da desigualdade foi menos acentuada nos bacharelados (média $=-36 \%$ ) que nas demais formações (média $=-60 \%$ ), e nas ofertas noturnas (média $=-22 \%$ ) que nas diurnas (média $=-52 \%$ ); não se observou uma diferença estatisticamente significante (ao nível de 5\%) entre cursos imperiais (Direito, Engenharias e Medicina) e não imperiais. Assim, detectou-se evidência em favor da hipótese $d$ : há indícios de que os efeitos da LdasC sobre a desigualdade no acesso tenham sido menos salientes nas ofertas com maior relação candidato/vaga, nos bacharelados e cursos noturnos. A próxima seção sintetiza os achados e os contextualiza, tendo como pano de fundo as indagações que motivaram o estudo.

\section{CONSIDERAÇÕES FINAIS}

Este trabalho norteou-se por duas questões de pesquisa. Para endereçar a primeira, sobre os mecanismos através dos quais a LdasC pode influenciar a alocação de vagas, efeitos potenciais da reserva de vagas foram descritos de acordo com sua atuação sobre a oferta de vagas, a demanda por essas vagas e notas mínimas para admissão. Enquanto os primeiros são dados pela própria expansão do percentual de assentos reservados, os impactos sobre a demanda são incertos, podendo origi- 
nar-se em diferentes tipos de resposta comportamental. Efeitos sobre as NdeC decorrem da interação entre oferta e demanda, e são também desconhecidos a priori.

Mobilizando a teoria das disposições incorporadas (Bourdieu, Passeron, 1964, 1970; Bourdieu, 1979, 1998), foram derivadas duas hipóteses quanto a movimentos na demanda resultantes da LdasC. Para a hipótese $a$, que prevê uma ampliação da participação do público-alvo entre os examinados mais bem preparados do ENEM, não se encontrou evidência empírica nos dados do ENEM 2011 a 2015 referentes a residentes da RMBH, concluintes do ensino médio e com 17 anos. Já a hipótese $b$, a qual postula uma ampliação da participação do público-alvo entre os candidatos à UFMG, foi confirmada pelos dados dos candidatos a cursos presenciais oferecidos nos campi de Belo Horizonte, nos processos seletivos de 2014 a 2017. Houve patente expansão do contingente de concorrentes às vagas reservadas, que passaram de $36,8 \%$ do total em 2014 para $45,8 \%$ no ano seguinte, tornando-se a maioria dos inscritos em 2016; o número de candidatos por oferta também se elevou nas modalidades reservadas, como indicam análises multivariadas com efeitos fixos de oferta. Em conjunto, esses achados sugerem que a LdasC aqueceu a demanda pelo ensino superior entre seu público-alvo, porém não revelam como essa ampliação da demanda se distribui entre níveis de preparo acadêmico.

A segunda questão de pesquisa indaga em que medida a LdasC reduz desigualdades sistemáticas no acesso ao ensino superior federal. Seu encaminhamento fundou-se no Axioma de Identificação de Roemer (1998) como abordagem para mensurar desigualdades de oportunidade no acesso; adicionalmente, atentou-se à noção de estratificação horizontal, pela qual grupos sociais distribuem-se heterogeneamente entre cursos e instituições, o que influencia as chances de alcançarem melhores trabalhos, rendimentos e outros resultados socialmente relevantes (Gerber, Cheung, 2008; Mont'Alvão, 2016; Carvalhaes, Ribeiro, 2017). Um experimento natural, com atribuição "como se" aleatória ao tratamento (neste caso, maior percentual de vagas reservadas em 2015 em relação a 2014) para indivíduos de certa idade, e uma estratégia de pareamento conhecida como fronteira de pareamento (matching frontier), possibilitam inferências causais no endereçamento dessa pergunta de pesquisa.

A evidência reunida dá suporte à hipótese $c$, indicando que a LdasC melhorou a posição dos elegíveis a M1 (modalidade de entrada que 
reúne o maior número de condições "desfavorecidas") em relação aos candidatos da livre concorrência. Em média, a desigualdade entre M1 e M5 reduziu-se em 43,5\% entre 2014 e 2015, favorecendo M1. Nesse sentido, a política federal de reserva de vagas parece aliviar desigualdades no acesso à UFMG, pelo menos no que concerne a candidatos concluintes do ensino médio no ano em que prestaram o ENEM. A quarta e última hipótese examinada, $d$, postula que a LdasC afeta a desigualdade no acesso em intensidades diferentes para diferentes ofertas de cursos. Encontrou-se respaldo empírico a essa hipótese, com menor redução percentual da desigualdade nas ofertas com maior relação candidato/vaga, nos bacharelados e cursos noturnos.

As análises aqui empreendidas, em particular aquelas afetas aos mecanismos de influência da LdasC, seriam enriquecidas com outros tipos de dados. Informações de natureza quantitativa, como as notas no ENEM dos candidatos à UFMG em cada modalidade, lançariam luz sobre a natureza de alterações na demanda (e.g., deslocamento de toda a curva para a direita no eixo das notas, elevação da participação dos candidatos com desempenho competitivo apenas). Ainda, pesquisa qualitativa, baseada em declarações de concluintes do ensino médio, examinados no ENEM e calouros da UFMG, coletadas em entrevistas ou grupos focais, propiciariam averiguar a adequação do referencial teórico utilizado na predição do comportamento da demanda, em termos de participação no ENEM e preparação acadêmica.

Enquanto as ações afirmativas no acesso ao ensino superior brasileiro constituem agenda de pesquisa já estabelecida, com importantes trabalhos desde meados dos anos 2000, ela permanece dinâmica. No que diz respeito à LdasC, há espaço para aprofundar avaliações - abarcando mais universidades, anos e outras medidas de desigualdade, inclusive atinentes às pessoas com deficiência, recentemente contempladas pelas cotas. Para além do acesso, faltam estudos sobre as interconexões entre a reserva de vagas e a assistência estudantil, e a inserção no mercado de trabalho, por exemplo. Esforços dessa natureza, além de elucidar os efeitos da LdasC, gerariam evidência relevante para calibrar, conforme necessário, essa política pública de alcance nacional e enorme visibilidade.

Submetido em 19 de dezembro de 2017

Aprovado em 8 de março de 2018 


\section{ERRATA}

Na página 405, Onde se lia:

“Ana Karruzé Departamento de Ciência Política da Universidade Federal de Minas Gerais, Belo Horizonte, MG, Brasil. (e-mail: apkarruz@gmail.com)."

\section{Leia-se:}

“Departamento de Ciência Política da Universidade Federal de Minas Gerais, Belo Horizonte, MG, Brasil. (e-mail: HYPERLINK "mailto:apkarruz@gmail.com)" apkarruz@gmail.com)."

Na página 406, Onde se lia:

"Renda (= 1,5 s.m. p.c.) comprovada"

Leia-se:

"Renda ( $\leq 1,5$ s.m. p.c.) comprovada"

Na página 429, Onde se lia:

“Teste Wald rejeita, a á = 5\%,Ho: Todos os âs = 0 ?"

Leia-se:

“Teste Wald rejeita, a $\alpha=5 \%$, Ho: Todos os $\beta \mathrm{s}=0$ ?"

Na página 433, Onde se lia:

(IV) $\quad$ ENEM $_{\text {imp }}-$ Corte $_{c f t m p}=\alpha+\beta^{*}$ Ano2015 $_{p}+\gamma \tilde{a}^{*}$ Controles $_{i}+\varepsilon_{\text {icftmp }}$

\section{Leia-se:}

(IV)

ENEM $_{\text {imp }}-$ Corte $_{c f t m p}=\alpha+\beta^{*}$ Ano2015 $p+\gamma^{*}$ Controles $_{i}+\varepsilon_{i c t m p}$

Na página 448, Onde se lia:

DADOS - Revista de Ciências Sociais, Rio de Janeiro, vol. 61, nº 2, 2018 
“Teste Wald rejeita, a á = 5\%,Ho: Todos os âs = 0 ?”

Leia-se:

“Teste Wald rejeita, a $\alpha=5 \%$, Ho: Todos os $\beta \mathrm{s}=0$ ?"

Na página 456, Onde se lia:

“* Ofertas no campus Pampulha (Belo Horizonte); (...)"

Leia-se:

"* Ofertas nos campi da UFMG de Belo Horizonte; (...)"

Na página 456, Onde se lia:

“** Estatisticamente significante a a $=5 \% . "$

Leia-se:

“** Estatisticamente significante a $\alpha=5 \% . "$

Na página 460, Onde se lia:

“* Ofertas no campus Pampulha (Belo Horizonte); (...)"

Leia-se:

"* Ofertas nos campi da UFMG de Belo Horizonte; (...)"

Na página 460, Onde se lia:

“** Estatisticamente significante a a $=5 \% . "$

Leia-se:

"** Estatisticamente significante a $\alpha=5 \% . "$

Na página 461, Onde se lia: 
"Porém, diversos aspectos dessa ação afirmativa podem comprometer sua eficácia."

\section{Leia-se:}

"Porém, diversos aspectos dessa ação afirmativa podem comprometer sua efetividade."

DADOS - Revista de Ciências Sociais, vol. 62(1): e20190003, 2019

DADOS - Revista de Ciências Sociais, Rio de Janeiro, vol. 61, n² 2, 2018 


\section{Ana Karruz}

\section{NOTAS}

1. O art. $3^{\circ}$ da LdasC passou a ter a seguinte redação: "Em cada instituição federal de ensino superior, as vagas de que trata o art. 1 을 desta Lei serão preenchidas, por curso e turno, por autodeclarados pretos, pardos e indígenas e por pessoas com deficiência, nos termos da legislação, em proporção ao total de vagas no mínimo igual à proporção respectiva de pretos, pardos, indígenas e pessoas com deficiência na população da unidade da Federação onde está instalada a instituição, segundo o último censo da Fundação Instituto Brasileiro de Geografia e Estatística - IBGE." (Brasil, 2016). A Lei no 13.409 / 2016 foi regulamentada pelo Decreto $\mathrm{n}-9.034$, de 20 de abril de 2017, e pela Portaria Normativa do Ministério da Educação (MEC) no 9, de 5 de maio de 2017; não afetou, assim, os processos seletivos realizados antes desta última data.

2. Resultados similares haviam sido encontrados por Velloso (2009), ainda antes da LdasC, num trabalho sobre cotas na Universidade de Brasília.

3. O ENEM é o principal teste de entrada para o ensino superior no Brasil. Aplicado anualmente desde 1998 a indivíduos voluntariamente inscritos, esse exame é administrado pelo Instituto Nacional de Estudos e Pesquisas Educacionais Anísio Teixeira (Inep), autarquia vinculada ao MEC.

4. Cálculo próprio, com base nos microdados do ENEM 2015.

5. Cálculo próprio, com base nos microdados do ENEM 2015.

6. Na UFMG, objeto deste estudo, o algoritmo de preenchimento das vagas foi reformado: “a universidade estabeleceu, a partir de 2016, uma nova regra de ingresso. Independentemente de se inscrever para vagas reservadas ou de ampla concorrência, os candidatos serão primeiramente agrupados na ampla concorrência e somente serão incluídos nas vagas destinadas às cotas se não obtiverem pontuação necessária na primeira. As consequências dessa mudança ainda não podem ser avaliadas." (Nogueira et al., 2017:30, nota de rodapé 13).

7. O Sisu - Sistema de Seleção Unificada é um sistema através do qual instituições de ensino superior públicas oferecem vagas em seus programas de graduação e recebem inscrições de candidatos participantes do ENEM. O Sisu é gerenciado pelo MEC

8. https://www.ufmg.br/conheca/nu_index.shtml.

9. Desde 2016, a UFMG tem um único processo seletivo, anual, baseado na primeira edição do Sisu de cada ano. Em cada um dos processos seletivos semestrais considerados nas análises relativas à questão 2 , ambos para ingresso no primeiro semestre (de 2014 e de 2015), a UFMG atraiu 186 mil candidatos (primeira ou segunda opção).

10. O Fundef (Fundo de Manutenção e Desenvolvimento do Ensino Fundamental e de Valorização do Magistério) estabeleceu uma nova organização para o financiamento do ensino fundamental, alocando a este $15 \%$ da arrecadação global de estados e municípios. O Fundeb (Fundo de Manutenção e Desenvolvimento da Educação Básica e de Valorização dos Profissionais da Educação) elevou para 20\% o percentual de contribuição de estados e municípios; também, a educação infantil e o ensino médio passaram a ser abrangidos pelo fundo, além de ter sido efetivada uma complementação com recursos federais nos estados onde o valor do fundo por aluno não atinge um mínimo nacional. 
11. A Prova Brasil é uma avaliação educacional realizada a cada dois anos pelo Inep, como parte do Sistema de Avaliação da Educação Básica (SAEB). É composta por testes de matemática e língua portuguesa aplicados aos alunos do ensino fundamental (5을 9 으 anos) das escolas públicas; a partir de 2017, passou a contemplar também o $3^{3}$ ำ ano do ensino médio, substituindo o ENEM como sistema de avaliação das instituições de ensino.

12. Em Alves, Soares e Xavier (2016), nível socioeconômico é operacionalizado a partir de um indicador construído com base na escolaridade e setor ocupacional dos pais, posse de itens de conforto e contratação de empregados domésticos no domicílio.

13. O termo "imperiais" remete ao Brasil Colônia, quando tais profissões se mostraram essenciais ao desenvolvimento brasileiro (Vargas, 2010).

14. Segundo a qual os indivíduos investem em educação para elevar a produtividade do fator humano de produção, como enunciado por Becker (1964).

15. É provável que o advento do Sisu tenha ampliado consideravelmente a racionalidade na demanda por cursos superiores, ponderam Nogueira et al. (2017:7): “No vestibular, o indivíduo se candidata a um curso e, em seguida, realiza um exame no qual precisa alcançar nota suficiente para ser aprovado. O Sisu inverte essa dinâmica: o indivíduo já tem uma nota e se candidata a dois cursos (em primeira e segunda opção) em relação aos quais ele já sabe com muito mais segurança do que no vestibular, dadas simulações feitas na etapa inicial do Sisu, suas possibilidades reais de ser aprovado".

16. Subcotas são percentuais destinados a grupos específicos dentro de cotas mais gerais (e.g., percentual para negros e indígenas dentre os assentos reservados aos egressos do ensino médio público).

17. Na UFMG, 6.009 vagas foram oferecidas em 2014, e 6.039 em 2017. Esta apuração considera apenas cursos de graduação presencial nos campi de Belo Horizonte, e cujo processo seletivo baseou-se exclusivamente no ENEM.

18. Esse conceito é emprestado da Economia do Trabalho, onde denota o quantitativo de pessoas trabalhando. Em contraste, a chamada margem intensiva da oferta de trabalho corresponde a quanto um dado número de pessoas trabalha, em média (Blundell, Bozio, Laroque, 2011).

19. Esse efeito da LdasC seria observado mesmo após se controlar pelas características da demanda, as quais podem variar entre processos seletivos.

20. Para aumentar a comparabilidade das observações, optou-se por excluir o campus de Montes Claros. No processo seletivo de 2017, esse campus ofertava $240(3,82 \%)$ das 6.279 vagas oferecidas pela UFMG.

21. Cursos com provas de habilidades específicas (e.g., dança, música) não são considerados neste trabalho.

22. Ciências da Natureza e suas Tecnologias; Ciências Humanas e suas Tecnologias; Linguagens, Códigos e suas Tecnologias; Matemática e suas Tecnologias; e Redação.

23. https://www2.ufmg.br/drca/drca/Home/Graduacao/Processos-Seletivos/SiSU-UFMG.

24. A interpretação desse desenho depende da produção de dois efeitos, com sinais opostos (Shadish, Cook, Campbell, 2002); neste caso, os efeitos esperados (estimados na próxima seção) são positivos para M1 a M4, e negativo para M5. O desenho proposto pressupõe que o efeito da reserva de vagas, se existente, ocorre em sentido contrário para não cotistas.

DADOS - Revista de Ciências Sociais, Rio de Janeiro, vol. 61, n² 2, 2018 


\section{Ana Karruz}

25. As restrições amostrais foram as seguintes (o primeiro valor dentro dos parênteses refere-se ao ENEM 2013; o segundo, ao ENEM 2014): eram residentes da RMBH (255.661; 317.034); tinham notas para todas as provas do exame e obtiveram nota maior que zero na redação $(171.266$; 205.453); dispunham da informação necessária para determinar sua elegibilidade às cotas $(167.632 ; 146.082)$; eram concluintes do ensino médio no ano em que prestaram o $\operatorname{ENEM~}(38.728$; 20.351); teriam 17 anos completos em 31 de dezembro de 2013 (18.020; 6.246); eram solteiros, não eram gestantes ou lactantes, não apresentavam necessidades especiais (por exemplo, em função de baixa visão ou déficit de atenção), nem tinham seus registros duplicados (17.919; 6.222).

26. Após testes Wald indicarem que M3 e M4 poderiam ser combinadas, o modelo foi recalculado com essa redução de cinco para quatro categorias (análise não mostrada, à disposição sob demanda). Tal reespecificação não alterou os resultados.

27. Análise não mostrada, à disposição sob demanda.

28. As análises consideram inscrições para a primeira ou a segunda opção de curso, e restringem-se à primeira (ou única) seleção vestibular de cada ano. Esta última contenção busca elevar a compatibilidade entre os processos seletivos investigados.

29. Média simples das proficiências constatadas na redação e áreas de conhecimento contempladas pelas quatro provas objetivas.

30. Se o examinado é elegível a M1, então sua nota no ENEM é comparada com a NdeC para cotistas M1, exclusivamente.

31. Tal variável pode ser entendida como proxy para a motivação e nível de expectativa do estudante em relação a seu rendimento no exame. Corresponde ao item "Indique os motivos que levaram você a participar do ENEM: Ingressar na Educação Superior Pública" (variável q026 nos microdados do ENEM 2013 e 2014). Essa questão solicitava que o respondente escolhesse um valor inteiro de 0 a 5 , em que 0 indicava o fator menos relevante e 5 o mais relevante entre os motivos para prestar o ENEM. A variável binária derivada desse item assume valor um se o indivíduo assinalou as alternativas 4 ou 5 .

32. Conjugadas, as amostras do ENEM 2013 (17.919) e 2014 (6.222) somam 24.141 indivíduos. Com vistas a acelerar o cômputo dos efeitos, extraiu-se uma subamostra aleatória de 25\% (6.035). Dos 3.115 examinados assim identificados e elegíveis a M1, 2.768 contavam com informação completa para as variáveis de pareamento; posteriormente, a subamostra pareada descartou $93,75 \%$ das observações. No caso do bacharelado noturno em Administração, por exemplo, restaram 173 observações na subamostra final de M1. Para M5, a subamostra aleatória continha 1.242 pessoas, das quais 1.236 dispunham de informação completa; após pruning de $87,50 \%$ das observações (no processo de pareamento), mantiveram-se 154 examinados na subamostra final da oferta bacharelado noturno em Administração. Para cada combinação de oferta e modalidade, houve um processo de pareamento específico, pois a matching frontier, além dos atributos individuais, considera a importância de cada variável de pareamento na previsão da variável dependente. Em todas as estimações, utiliza-se como métrica de imbalance a distância de Mahalanobis, e como quantidade de interesse, a FSATT - feasible sample average treatment effect on the treated; a FSATT implica que o efeito é computado tomando-se apenas unidades tratadas para as quais um bom par existe (King, Lucas, Nielsen, 2017). 


\section{REFERÊNCIAS BIBLIOGRÁFICAS}

AGÊNCIA DE NOTÍCIAS DA UFMG. (2017), Com Mais de 170 Mil Inscrições, UFMG é a Instituição Mais Procurada nesta Edição do Sisu. 06 de fevereiro de 2017. Disponível em https://www.ufmg.br/sisu/noticias/046557/.

ALVES, Maria Teresa Gonzaga; SOARES, José Francisco; XAVIER, Flavia Pereira. (2016), "Desigualdades Educacionais no Ensino Fundamental de 2005 a 2013: Hiato entre Grupos Sociais". Revista Brasileira de Sociologia, vol. 4, no 7, pp. 49-81.

ARTES, Amélia; RICOLDI, Arlene Martinez. (2015), “Acesso de Negros no Ensino Superior: O que Mudou entre 2000 e 2010". Cadernos de Pesquisa, vol. 45, no 158, pp. 858-881.

ATHEY, Susan; IMBENS, Guido. (2015). “A Measure of Robustness to Misspecification”. American Economic Review: Papers and Proceedings, vol. 105, no 5, pp. 476-480.

BECKER, Gary. (1964), Human Capital. New York, National Bureau of Economic Research.

BLUNDELL, Richard; BOZIO, Antoine; LAROQUE, Guy. (2011), Extensive and Intensive Margins of Labour Supply: Working Hours in the US, UK and France. Bonn, Institute for the Study of Labor - ISA. (Discussion Paper no 6051).

BOUDON, Raymond. (1979), L'inégalité des Chances. Paris: Armand Colin.

BOUDON, Raymond. (2000), “Les Causes de l'Inégalité des Chances Scolaires", in R. BOUDON, C-H. CUIN e A. MASSOT. (orgs.), L'Axiomatique de l'Inégalité des Chances. Paris, L'Harmattan, pp. 533-542.

BOURDIEU, Pierre. (1979), La Distinction. Paris, Les Éditions de Minuit.

BOURDIEU, Pierre. (1998), Escritos de Educação. Petrópolis, Vozes.

BOURDIEU, Pierre; PASSERON, Jean-Claude. (1964), Les Héritieres: Les Étudiants et la Culture. Paris, Le Éditions de Minuit.

BOURDIEU, Pierre; PASSERON, Jean-Claude. (1970), La Reproduction: Éléments pour une Théorie du Système d'Enseignement. Paris, Les Éditions de Minuit.

BRAGA, Mauro M.; PEIXOTO, Maria do C. L.; BOGUTCHI, Tânia F. (2000), “A Demanda por Vagas no Ensino Superior: Análise dos Vestibulares da UFMG na Década de 90", in Anped, Anais da 23a Reunião Anual da Anped.

BRASIL. (2012a), Lei no 12.711, de 29 de agosto de 2012. Disponível em http: / / www.planalto.gov.br/ccivil_03/_ato2011-2014/2012/lei/112711.htm.

BRASIL - Instituto Nacional de Ciência e Tecnologia e Inclusão no Ensino Superior e na Pesquisa (INCT Inclusão). (2012b), Mapa das Ações Afirmativas: Instituições Públicas de Ensino Superior. Disponível em http://www.inctinclusao.com.br/acoes-afirmativas/mapa.

BRASIL. (2016), Lei no 13.409, de 28 de dezembro de 2016. Disponível em http:/ / www.planalto.gov.br/ccivil_03/_Ato2015-2018/2016/Lei/L13409.htm\#art1.

CAMPOS, Luiz Augusto; FERES JÚNIOR, João; DAFLON, Verônica Toste. (2014). O Desempenho de Cotistas no ENEM: Comparando as Notas de Corte do SISU. Rio de Janeiro,

DADOS - Revista de Ciências Sociais, Rio de Janeiro, vol. 61, n² 2, 2018 


\section{Ana Karruz}

Instituto de Estudos Sociais e Políticos, Universidade do Estado do Rio de Janeiro. (Texto para discussão GEMAA no 4 ).

CAMPOS, Luiz Augusto; STORNI, Tiago; FERES JÚNIOR, João. (2014). A Cor do ENEM-2012: Comparações entre o Desempenho de Brancos, Pardos e Pretos. Rio de Janeiro, Instituto de Estudos Sociais e Políticos, Universidade do Estado do Rio de Janeiro. (Texto para discussão GEMAA no 8).

CARVALHAES, Flavio; RIBEIRO, Carlos Costa. (2017), Estratificação Horizontal da Educação Superior no Brasil: Desigualdades de Classe, Gênero e Raça em um Contexto de Expansão Educacional. Rio de Janeiro, Núcleo Interdisciplinar de Estudos da Desigualdade/Centro de Estudos da Riqueza e da Estratificação Social - UFRJ/UERJ. (Working paper).

COLLARES, Ana Cristina Murta. (2010), Educational Inequalities and the Expansion of Postsecondary Education in Brazil, from 1982 to 2006. Tese (Doutorado em Sociologia), University of Wisconsin, Madison.

CORBUCCI, Paulo Roberto. (2014), A Evolução do Acesso de Jovens à Educação Superior do Brasil. Brasília, Instituto de Pesquisa Econômica Aplicada. (Texto para Discussão no 1950).

DAFLON, Verônica Toste; FERES JÚNIOR, João; CAMPOS, Luiz Augusto. (2013), "Ações Afirmativas Raciais no Ensino Superior Público Brasileiro: Um Panorama Analítico". Cadernos de Pesquisa, vol. 43, no 148, pp. 302-327.

DUNNING, Thad. (2008), "Improving Causal Inference: Strengths and Limitations of Natural Experiments". Political Research Quarterly, vol. 61, no 2, p. 282-293.

DURU-BELLAT, Marie. (2012), Access to Higher Education: What Counts as Fairness in Both an Individual and Systemic Perspective? Paris, Laboratoire Interdisciplinaire d'Évaluation des Politiques Publiques (LIEPP) - Sciences Po. (Methodological Discussion Paper no 1).

FIGUEIRÊDO, Erik; NOGUEIRA, Lauro; SANTANA, Fernanda Leite. (2014), “Igualdade de Oportunidades: Analisando o Papel das Circunstâncias no Desempenho do ENEM". Revista Brasileira de Economia, vol. 68, no 3, p. 373-392.

FRANCIS, Andrew M.; TANNURI-PIANTO, Maria. (2012), “The Redistributive Equity of Affirmative Action: Exploring the Role of Race, Socioeconomic Status, and Gender in College Admissions". Economics of Education Review, vol. 31, no 1, pp. 45-55.

GERBER, Theodore P.; CHEUNG, Sin Yi. (2008), “Horizontal Stratification in Postsecondary Education: Forms, Explanations, and Implications". Annual Review of Sociology, vol. 34, no 1, pp. 299-318.

GOLGHER, André Braz. (2010a), Diálogos com o Ensino Médio 5: A Escola de Ensino Médio no Brasil Analisada a Partir de Dados do INEP. Belo Horizonte, Cedeplar/UFMG. (Texto para Discussão).

GOLGHER, André Braz. (2010b), Diálogos com o Ensino Médio 6: O Estudante de Ensino Médio no Brasil Analisado a Partir de Dados do INEP. Belo Horizonte, Cedeplar/UFMG. (Texto para Discussão). 
GOLGHER, André Braz; AMARAL, Ernesto F. L.; NEVES, Alan Vítor C. (2015), “Desempenho Acadêmico dos Estudantes da UFMG: Uma Análise da Política de Bônus Sociorracial". Ciências Sociais em Perspectiva, vol. 14, № 26, pp. 120-145.

INEP - Instituto Nacional de Estudos e Pesquisas Educacionais Anísio Teixeira. (2016), Resumo Técnico: Censo da Educação Superior 2014. Brasília, Instituto Nacional de

Estudos e Pesquisas Educacionais Anísio Teixeira.

KING, Gary; LUCAS, Christopher; NIELSEN, Richard A. (2017), “The Balance-Sample Size Frontier in Matching Methods for Causal Inference". American Journal of Political Science, vol. 61, no 2, pp. 473-489.

LAHIRE, Bernard. (1999), "De la Théorie de l'Habitus à une Sociologie Psychologique”, in B. Lahire (org.), Le Travail Sociologique de Pierre Bourdieu. Paris, La Découverte.

LAHIRE, Bernard. (2002), Portraits Sociologiques, Paris, Nathan.

LAHIRE, Bernard. (2006), A Cultura dos Indivíduos. Porto Alegre, Artmed.

LONG, J. Scott; FREESE, Jeremy. (2001), Regression Models for Categorical Dependent Variables Using Stata. College Station, Stata Press.

MARTINS, Felipe dos S.; MACHADO, Danielle C. (2015), Determinantes do Acesso ao Ensino Superior no Brasil e a Probabilidade de Sucesso por Curso. Rio de Janeiro, IPEA. (Seminário Dimac no 467).

MEDEIROS, Hugo Augusto Vasconcelos; DEUS E MELLO NETO, Ruy de; GOMES, Alfredo Macedo. (2016), "Limites da Lei de Cotas nas Universidades Públicas Federais". Arquivos Analíticos de Políticas Educativas, vol. 24, no 6, pp. 1-20.

MENDES JUNIOR, Alvaro Alberto Ferreira; WALTENBERG, Fábio Domingues. (2015), "Políticas de Cotas Não Raciais Aumentam a Admissão de Pretos e Pardos na Universidade? Simulações para a UERJ". Planejamento e Políticas Públicas, no 44, pp. 229-256.

MONT'ALVÃO, Arnaldo. (2011), "Estratificação Educacional no Brasil do Século XXI". DADOS - Revista de Ciências Sociais, vol. 54, no 2, pp. 389 a 430.

MONT'ALVÃO, Arnaldo. (2016), “As Dimensões Vertical e Horizontal da Estratificação Educacional". Teoria e Cultura, vol. 11, no 1, p. 13-20.

MONTMARQUETTE, Claude; CANNINGS, Kathy; MAHSEREDJIAN, Sophie. (2002), "How do young people choose college majors?". Economics of Education Review, vol. 21, no 6, pp. 543-556.

NEVES, Clarissa E. Baeta; MARTINS, Carlos Benedito. (2016). “Ensino Superior no Brasil: Uma Visão Abrangente", in T. Dwyer et al. (orgs.), Jovens Universitários em um Mundo em Transformação: Uma Pesquisa Sino-brasileira. Brasília, Ipea; Pequim, SSAP, pp. 95-124.

NOGUEIRA, Cláudio M. M. (2012), “Escolha Racional ou Disposições Incorporadas: Diferentes Referenciais Teóricos na Análise Sociológica do Processo de Escolha dos Estudos Superiores". Estudos de Sociologia, vol. 2, no 18.

NOGUEIRA, Cláudio M. M.; NOGUEIRA, M. A. (2015), “Os Herdeiros: Fundamentos para uma Sociologia do Ensino Superior". Educação \& Sociedade, vol. 36, no 130, p. $47-62$.

DADOS - Revista de Ciências Sociais, Rio de Janeiro, vol. 61, n² 2, 2018 


\section{Ana Karruz}

NOGUEIRA, Cláudio M. M. et al. (2017), “Promessas e Limites: O Sisu e sua Implementação na Universidade Federal de Minas Gerais". Educação em Revista, v. 33, e161036.

PICANÇO, Felícia. (2016), “Juventude e Acesso ao Ensino Superior no Brasil - Onde está o Alvo das Políticas de Ação Afirmativa". Latin American Research Review, vol. 51, no 1, p. 109-131.

QUEIROZ, Zandra C. L. S. et al. (2015), “A Lei de Cotas na Perspectiva do Desempenho Acadêmico na Universidade Federal de Uberlândia". Revista Brasileira de Estudos Pedagógicos, vol. 96, no 243, pp. 299-320.

QUEIROZ, Delcele Mascarenhas; SANTOS, Jocélio Teles dos. (2006), "Sistema de Cotas: Um Debate. Dos Dados à Manutenção de Privilégios e de Poder". Educação E Sociedade, vol. 27, no 96 - Especial, pp. 717-737.

RIBEIRO, Carlos Costa; CENEVIVA, Ricardo; BRITO, Murillo Marschner Alves. (2015), “A Estratificação Educacional entre Jovens no Brasil: 1960 a 2010", in M. Arretche (org.), Trajetórias das Desigualdades: Como o Brasil Mudou nos Últimos Cinquenta Anos. São Paulo: Editora da UNESP, pp. 79-108.

RIBEIRO, Carlos Costa; SCHLEGEL, Rogerio. (2015), “A Estratificação Horizontal da Educação Superior no Brasil (1960 a 2010)", in M. Arretche (org.), Trajetórias das Desigualdades: Como o Brasil Mudou nos Últimos Cinquenta Anos. São Paulo: Editora da UNESP, pp. 133-162.

ROEMER, John E. (1998), Equality of Opportunity. Cambridge: Harvard University Press.

ROSENBAUM, Paul R.; RUBIN, Donald. (1983), "The Central Role of the Propensity Score in Observational Studies for Causal Effects". Biometrika, vol. 70, no 1, pp. 41-55.

SABBAGH, Daniel. (2011), “The Rise of Indirect Affirmative Action: Converging Strategies for Promoting 'Diversity' in Selective Institutions of Higher Education in the United States and France". World Politics, vol. 63, no 3, pp. 470-508.

SHADISH, William R.; COOK, Thomas D.; CAMPBELL, Donald T. (2002), Experimental and Quasi-Experimental Designs for Generalized Causal Inference. Houghton, Mifflin and Company.

SOARES, José Francisco; JÚDICE, Renato. (2003), “A Auto-Exclusão dos Alunos das Escolas Públicas Estaduais de Belo Horizonte no Vestibular da UFMG". Ensaio Pesquisa em Educação em Ciências, vol. 5, no 2, pp. 92-99.

STOCK, James H; WATSON, Mark W. (2003), Introduction to Econometrics. Boston, Pearson-Addison Wesley.

TAKAHASHI, Ricardo H. C.; CAMINHAS, Walmir M.; PENA, Carolina S. (2015), Mudanças no Ensino de Graduação da UFMG: Análise e Perspectivas. Disponível em https://www.ufmg.br/prograd/arquivos/acontece/ApEst.pdf.

TELLES, Edward; PAIXÃO, Marcelo. (2013), "Affirmative Action in Brazil". LASA Forum, vol. 44, no 2, pp. 10-11.

VALENTE, Rubia R.; BERRY, Brian J. L. (2017), "Performance of Students Admitted through Affirmative Action in Brazil". Latin American Research Review, vol. 52, no 1, pp. 18-34. 
VARGAS, Hustana Maria. (2010), “Sem Perder a Majestade: 'Profissões Imperiais' no Brasil”. Estudos de Sociologia, vol. 15, no 28, pp. 107-124.

VELLOSO, Jacques. (2009), “Cotistas e Não-Cotistas: Rendimento de Alunos na Universidade de Brasília". Cadernos de Pesquisa, vol. 39, no 137, pp. 621-644.

VILELA, Lara; MENEZES-FILHO, Naercio; TACHIBANA; Thiago Yudi. (2016), As Cotas nas Universidades Públicas Diminuem a Qualidade dos Alunos Selecionados? Simulações com Dados do ENEM. São Paulo, Insper - Centro de Políticas Públicas. (Policy Paper no 17).

WAINER, Jacques; MELGUIZO, Tatiana. (2017), “Políticas de Inclusão no Ensino Superior: Avaliação do Desempenho dos Alunos Baseado no Enade de 2012 a 2014". Educação e Pesquisa, Epub 12-Jan-2017.

WEIMER, David L.; VINING, Aidan R. (2004), Policy Analysis: Concepts and Practice. Upper Saddle River, Routledge. 
Ana Karruz

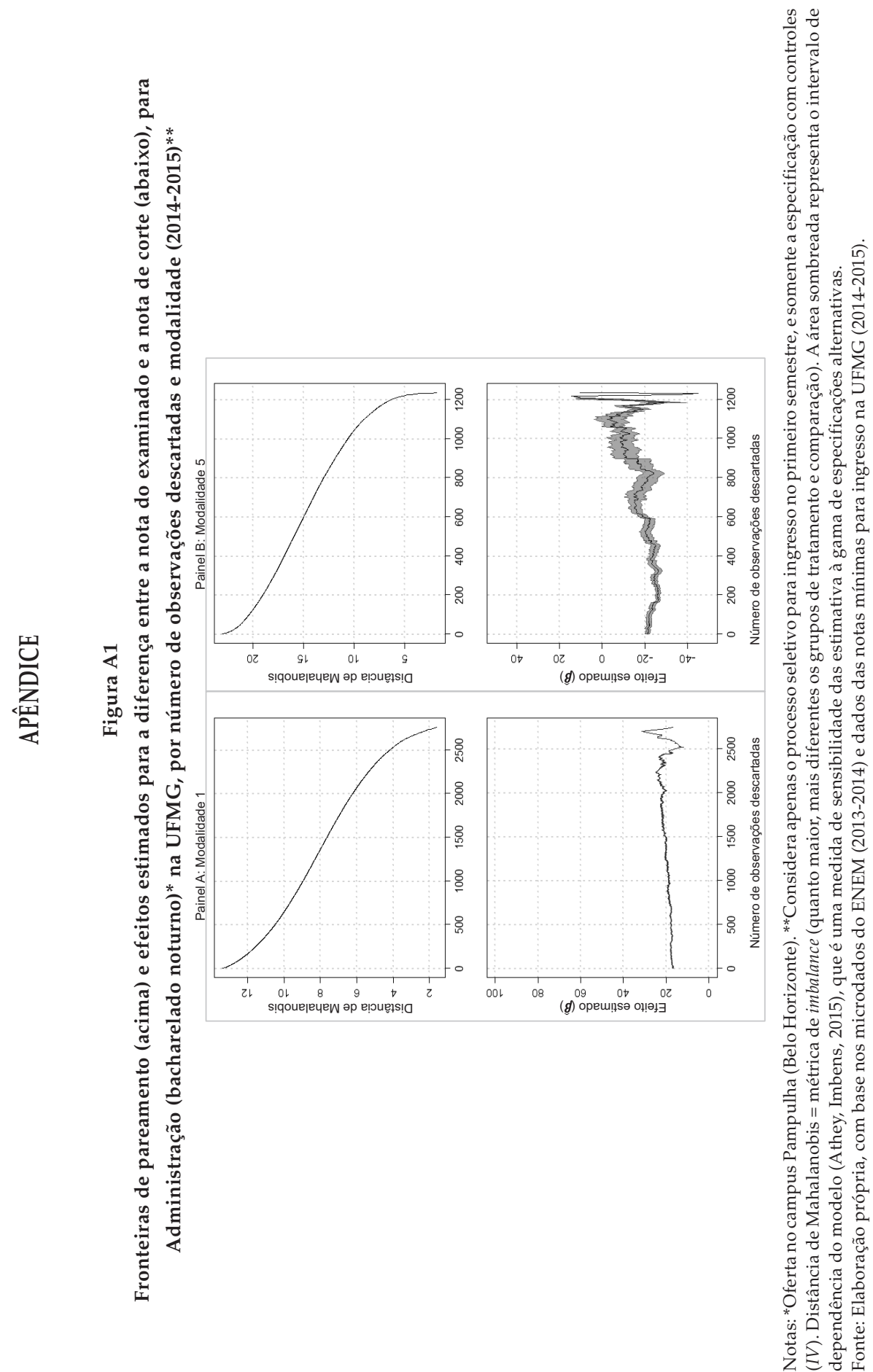

447 DADOS - Revista de Ciências Sociais, Rio de Janeiro, vol. 61, ำ 2, 2018 
Oferta, Demanda e Nota de Corte
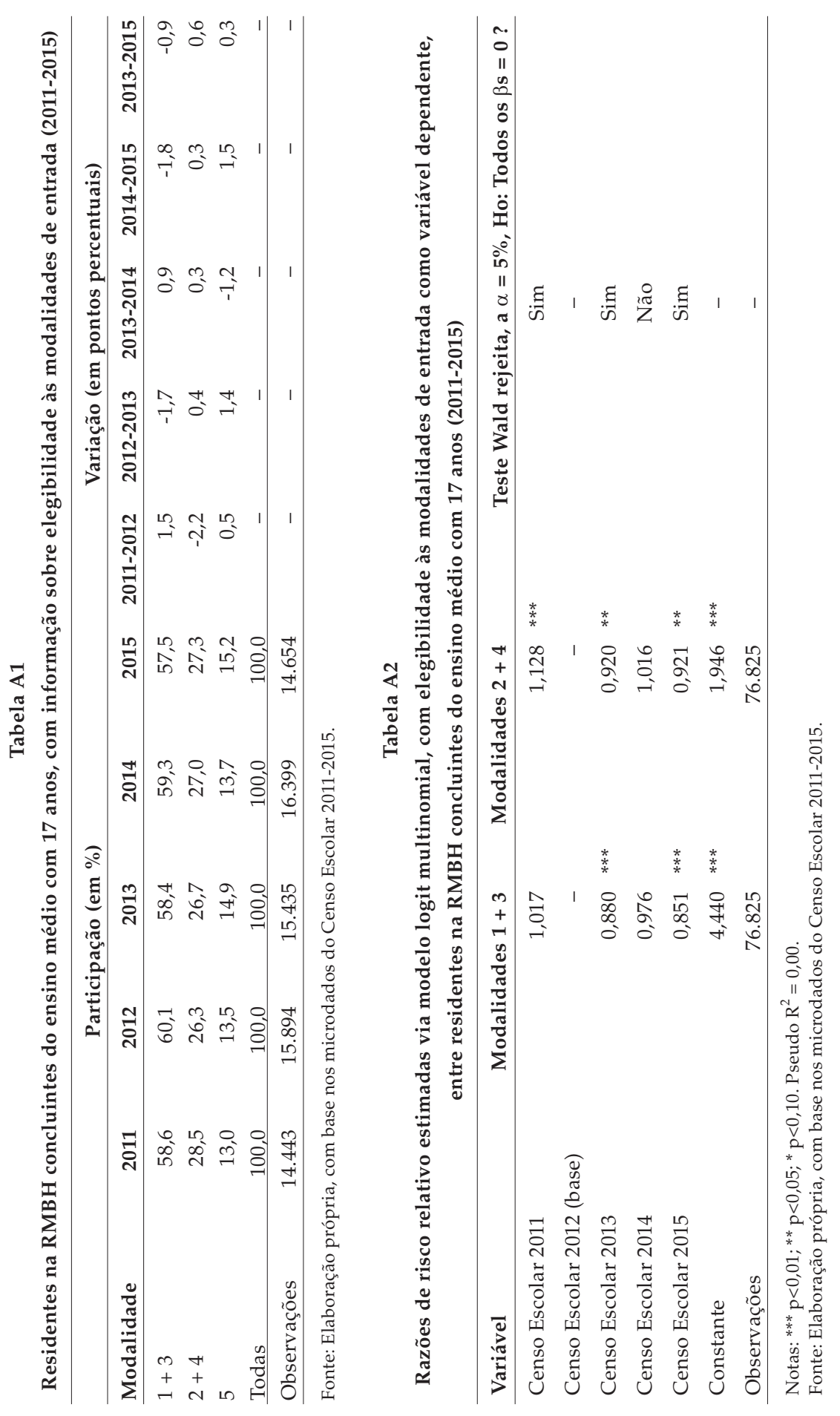

DADOS - Revista de Ciências Sociais, Rio de Janeiro, vol. 61, nํ2, 2018 


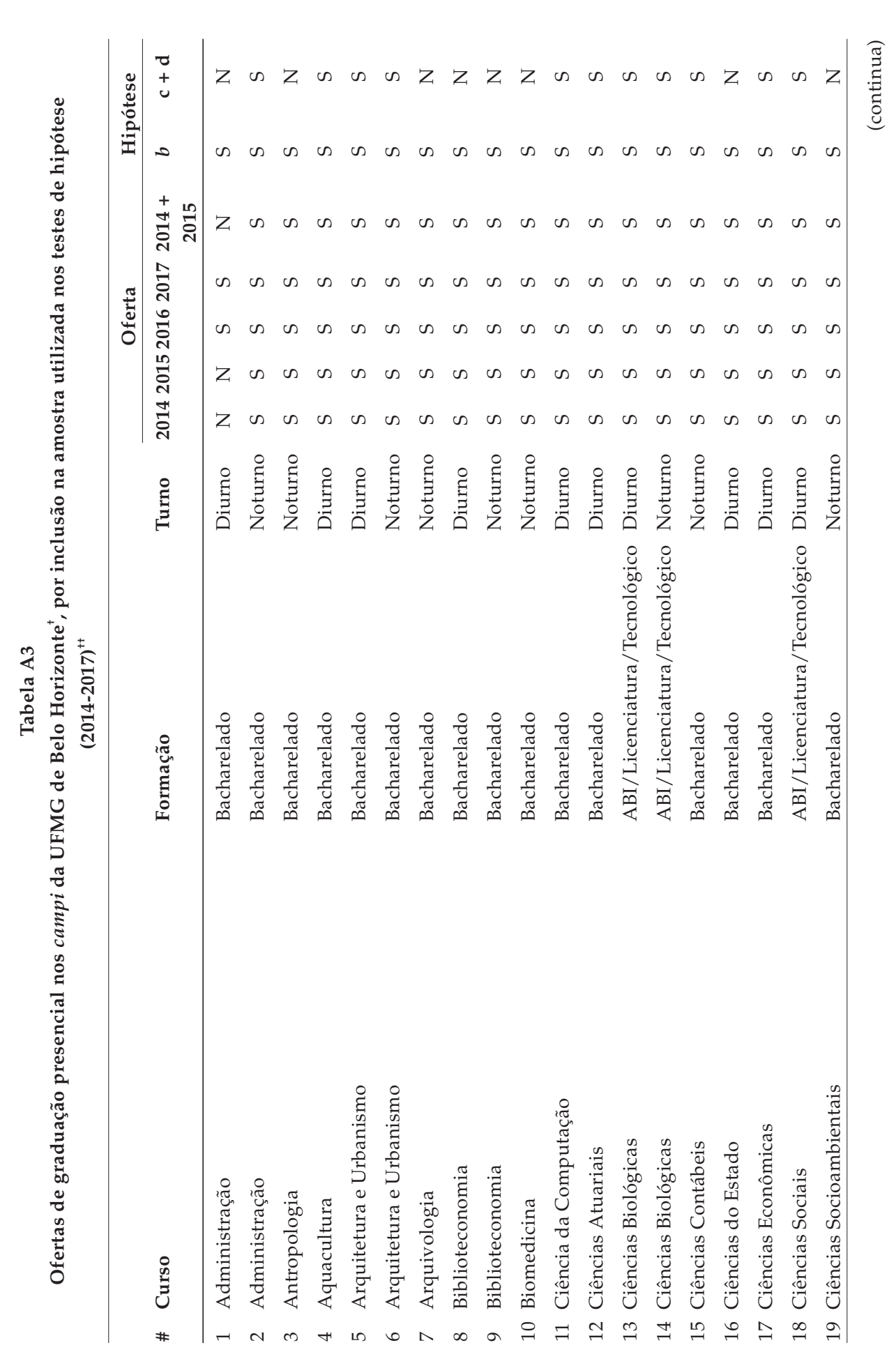

449 DADOS - Revista de Ciências Sociais, Rio de Janeiro, vol. 61, nº 2, 2018 
Oferta, Demanda e Nota de Corte

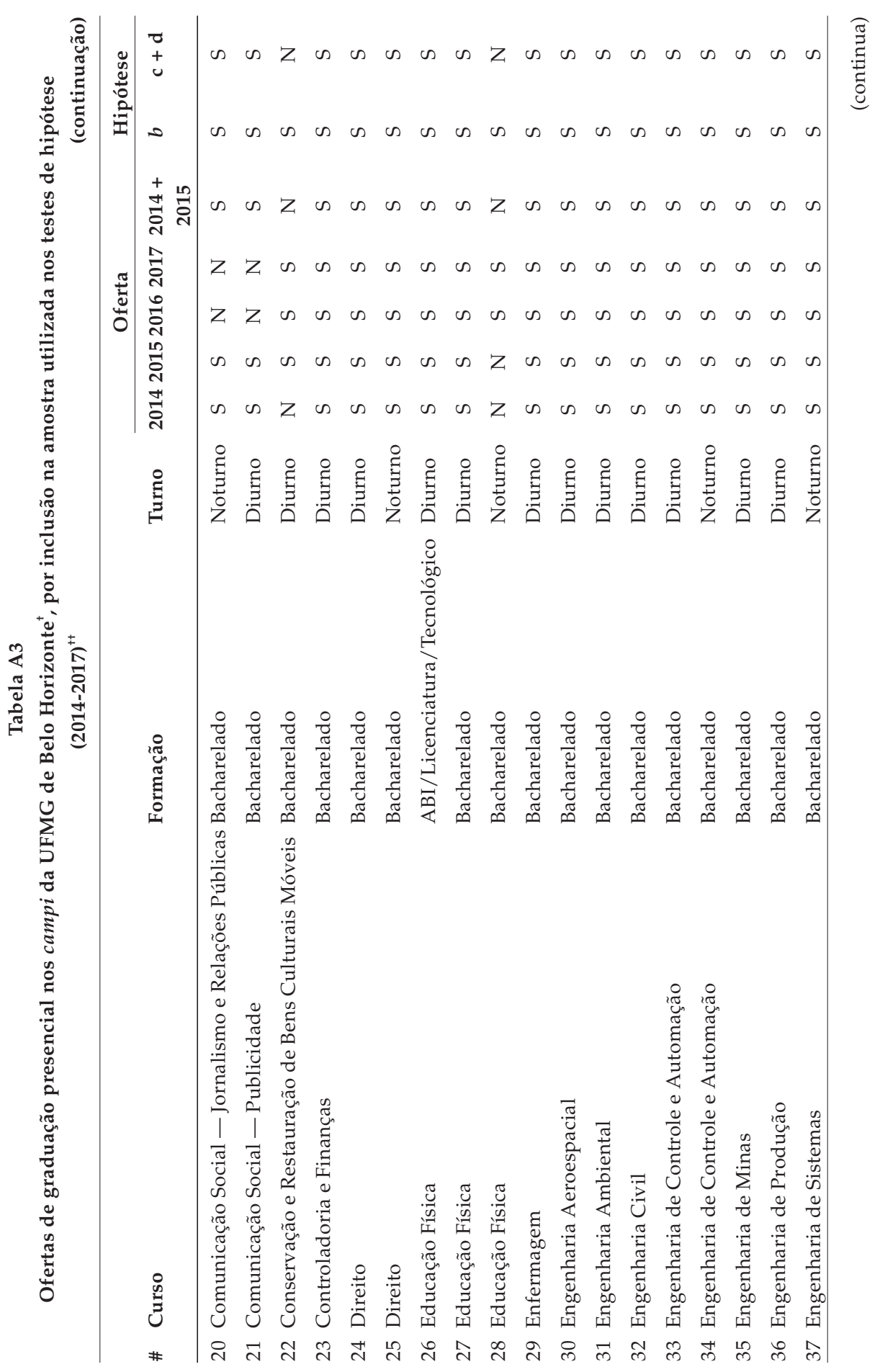

DADOS - Revista de Ciências Sociais, Rio de Janeiro, vol. 61, nํ2, 2018 
Ana Karruz

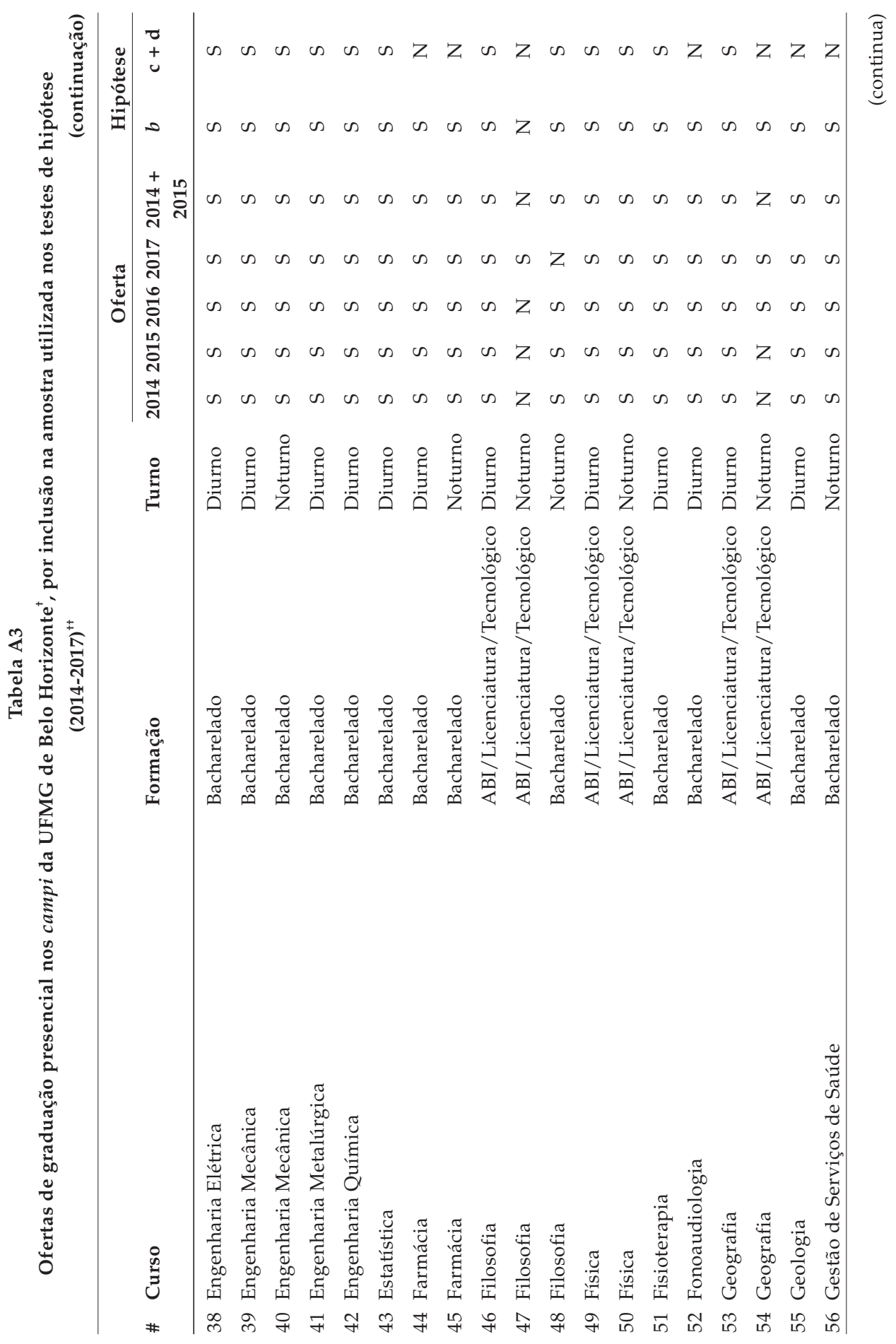

451 DADOS - Revista de Ciências Sociais, Rio de Janeiro, vol. 61, no 2, 2018 
Oferta, Demanda e Nota de Corte

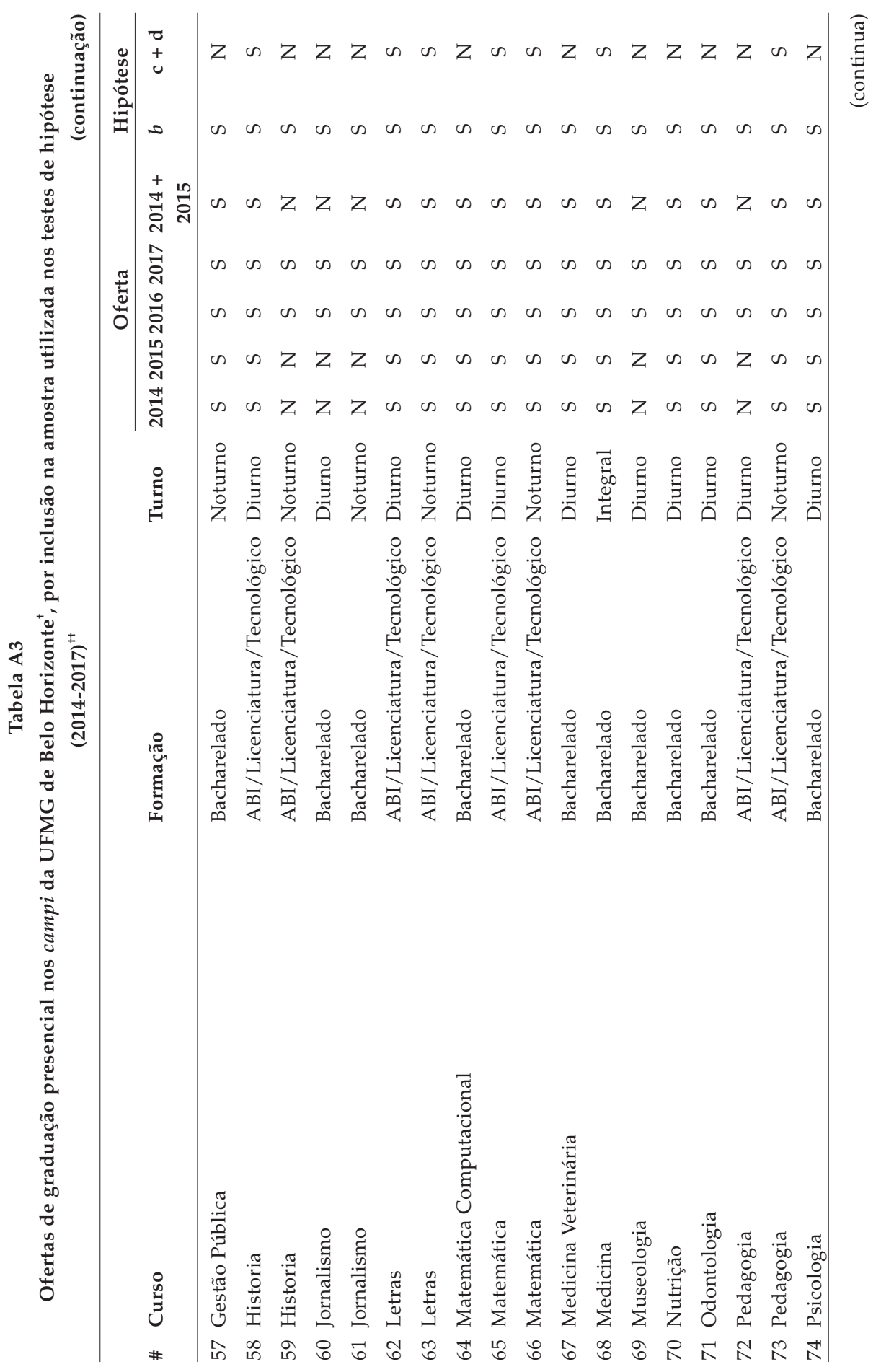

DADOS - Revista de Ciências Sociais, Rio de Janeiro, vol. 61, nํ2, 2018 
Ana Karruz

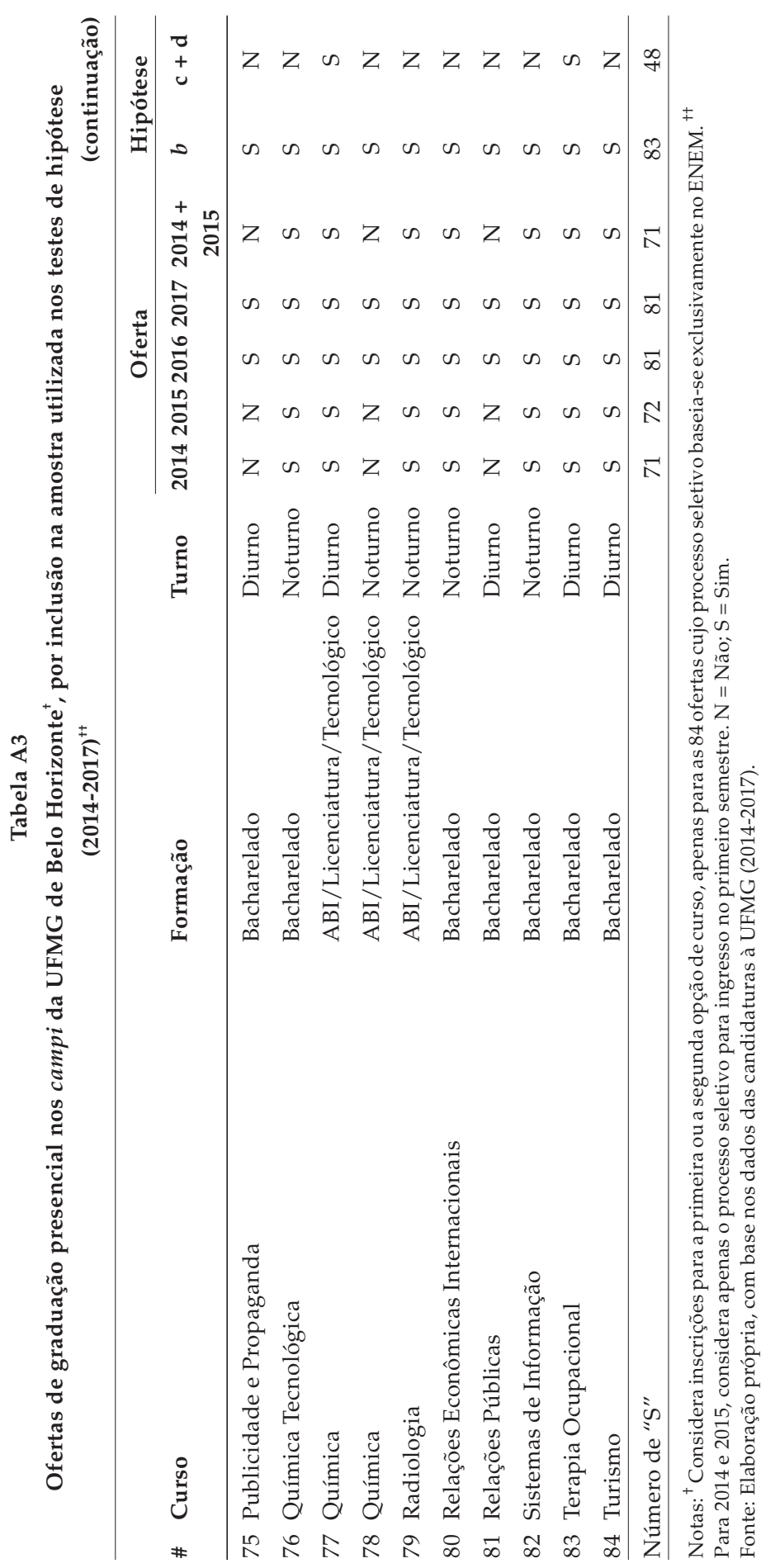

453

DADOS - Revista de Ciências Sociais, Rio de Janeiro, vol. 61, nº 2, 2018 
Oferta, Demanda e Nota de Corte

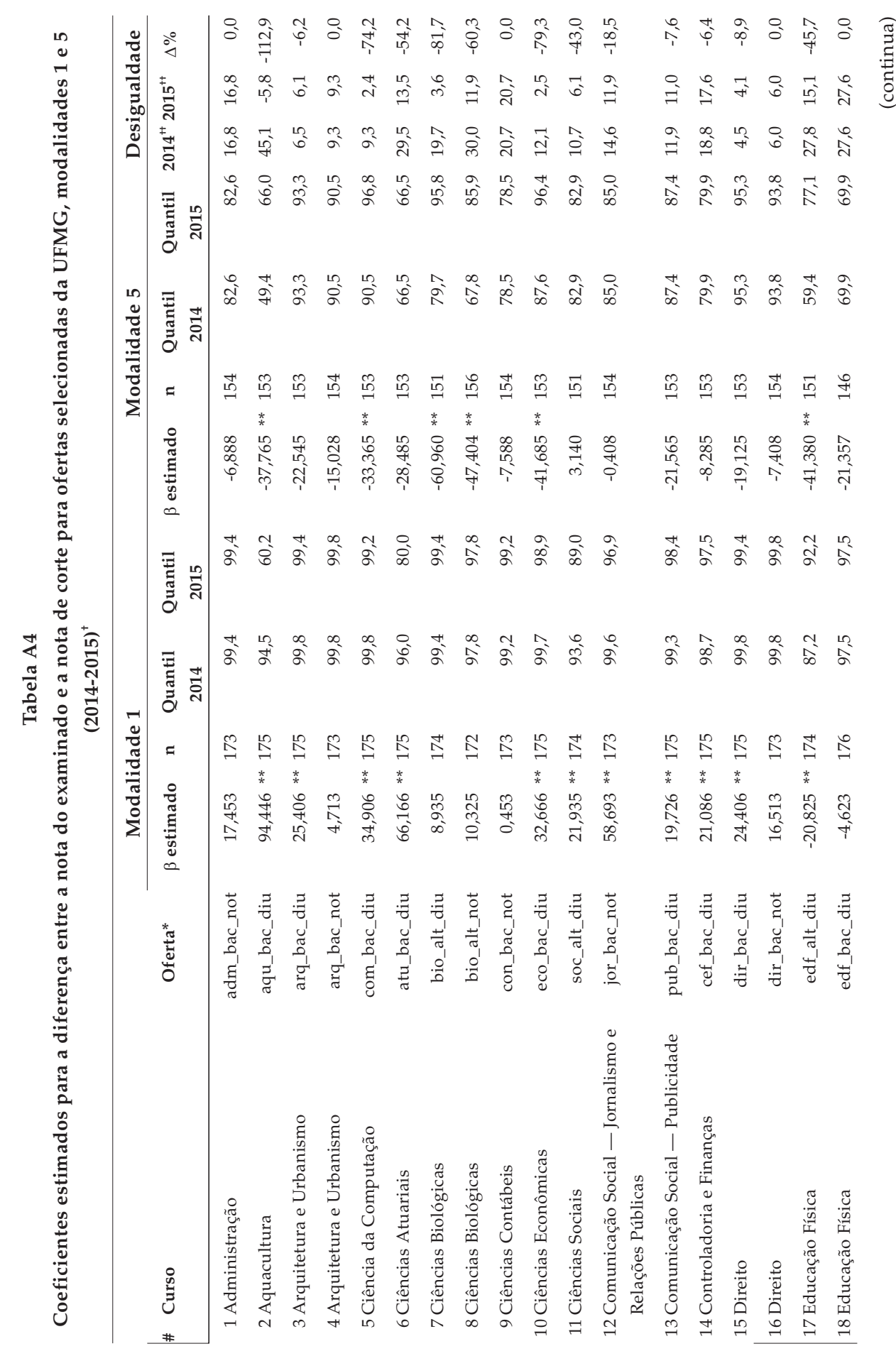

DADOS - Revista de Ciências Sociais, Rio de Janeiro, vol. 61, nํ2, 2018 
Ana Karruz

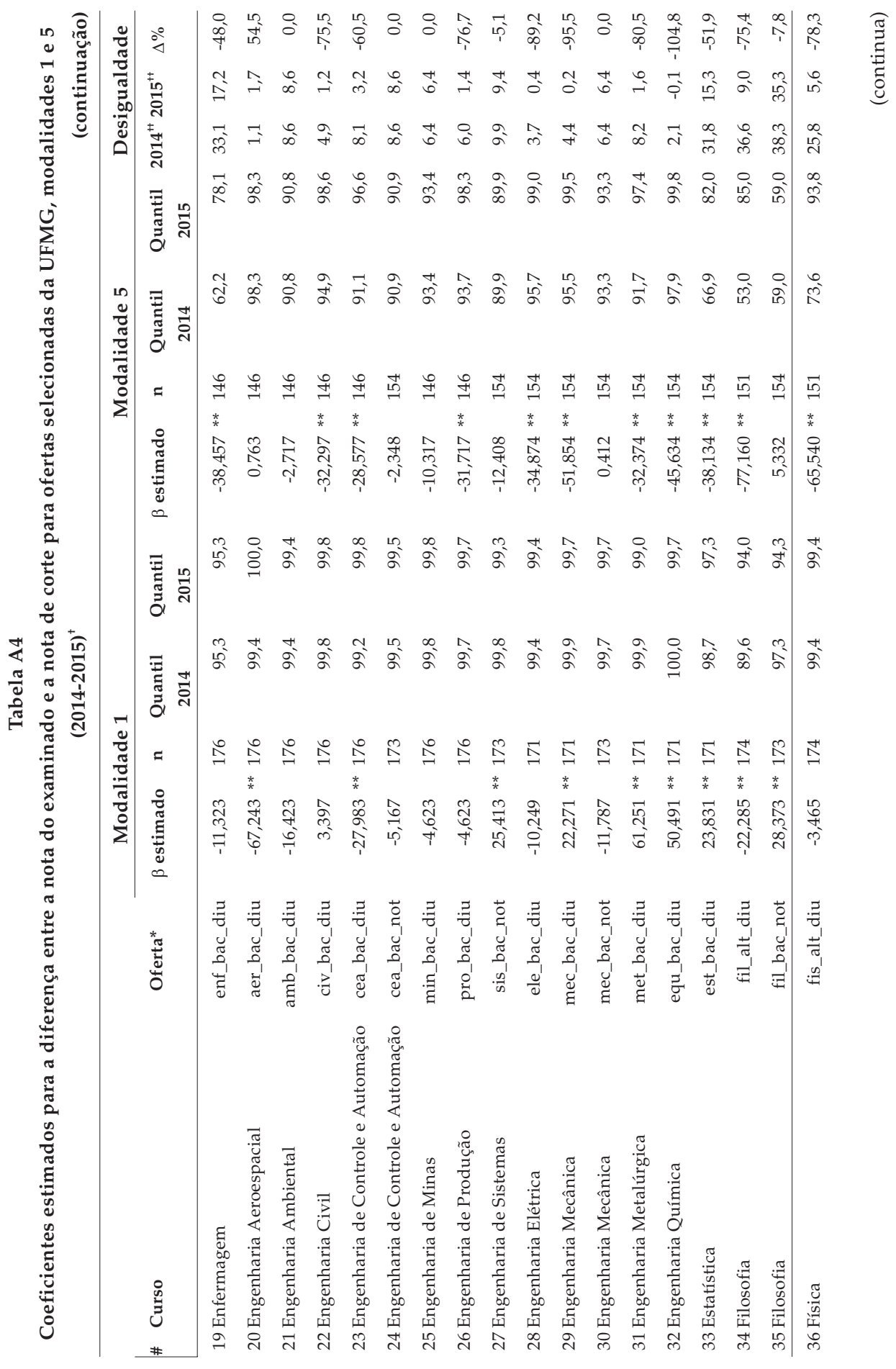

455 DADOS - Revista de Ciências Sociais, Rio de Janeiro, vol. 61, ำ 2, 2018 
Oferta, Demanda e Nota de Corte

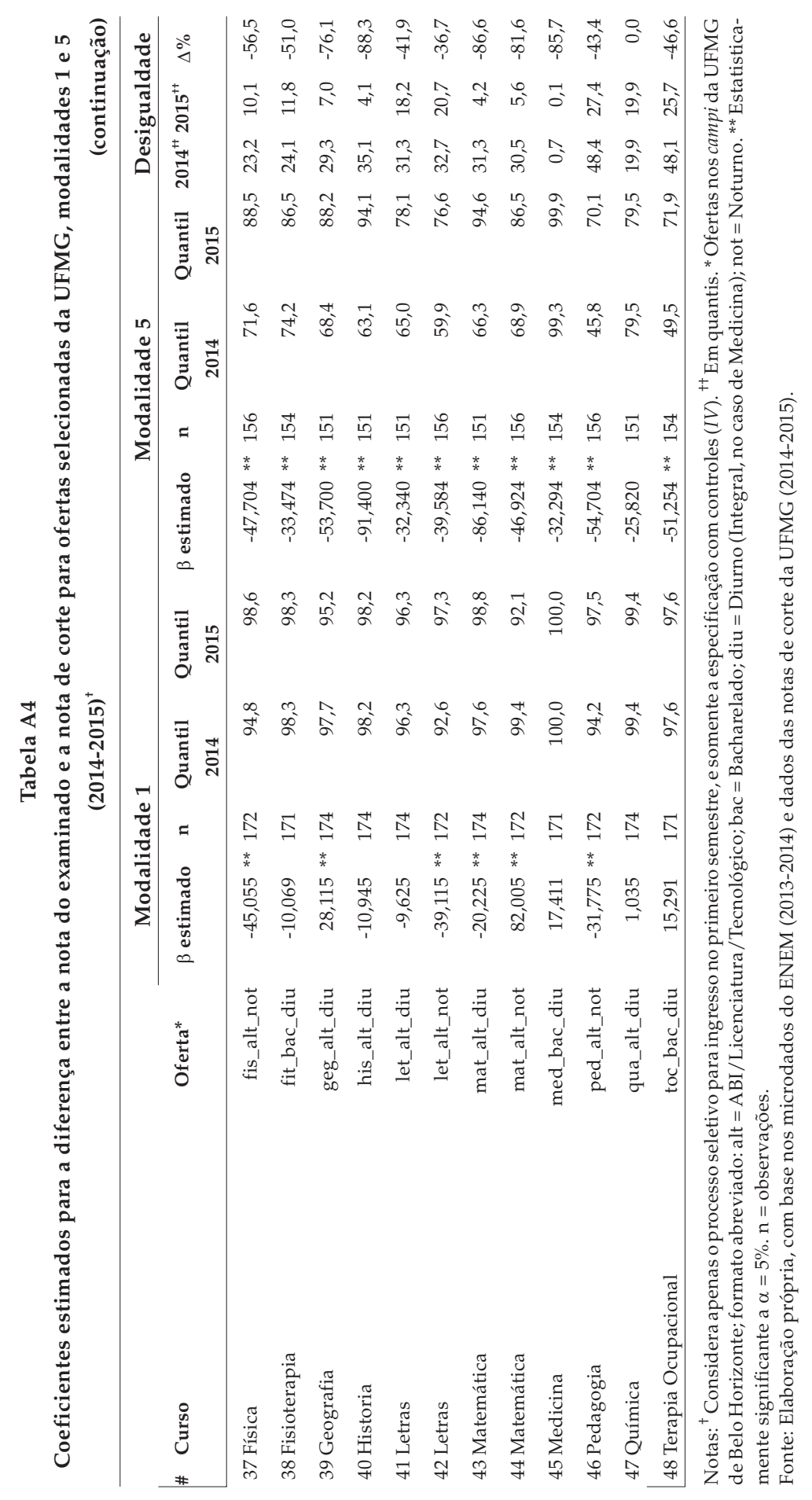

DADOS - Revista de Ciências Sociais, Rio de Janeiro, vol. 61, nํ2, 2018 


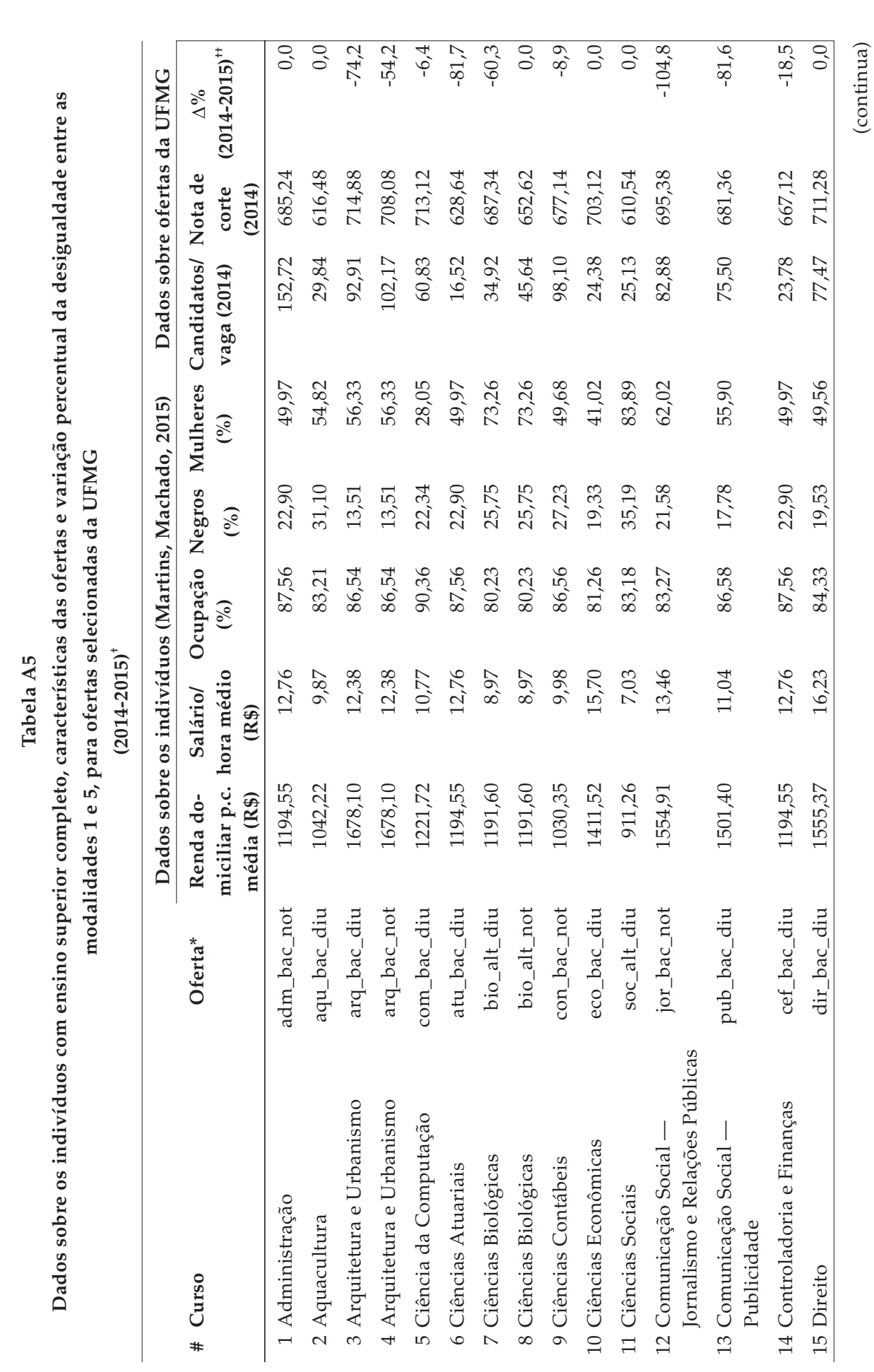

457 DADOS - Revista de Ciências Sociais, Rio de Janeiro, vol. 61, ำ 2, 2018 
Oferta, Demanda e Nota de Corte

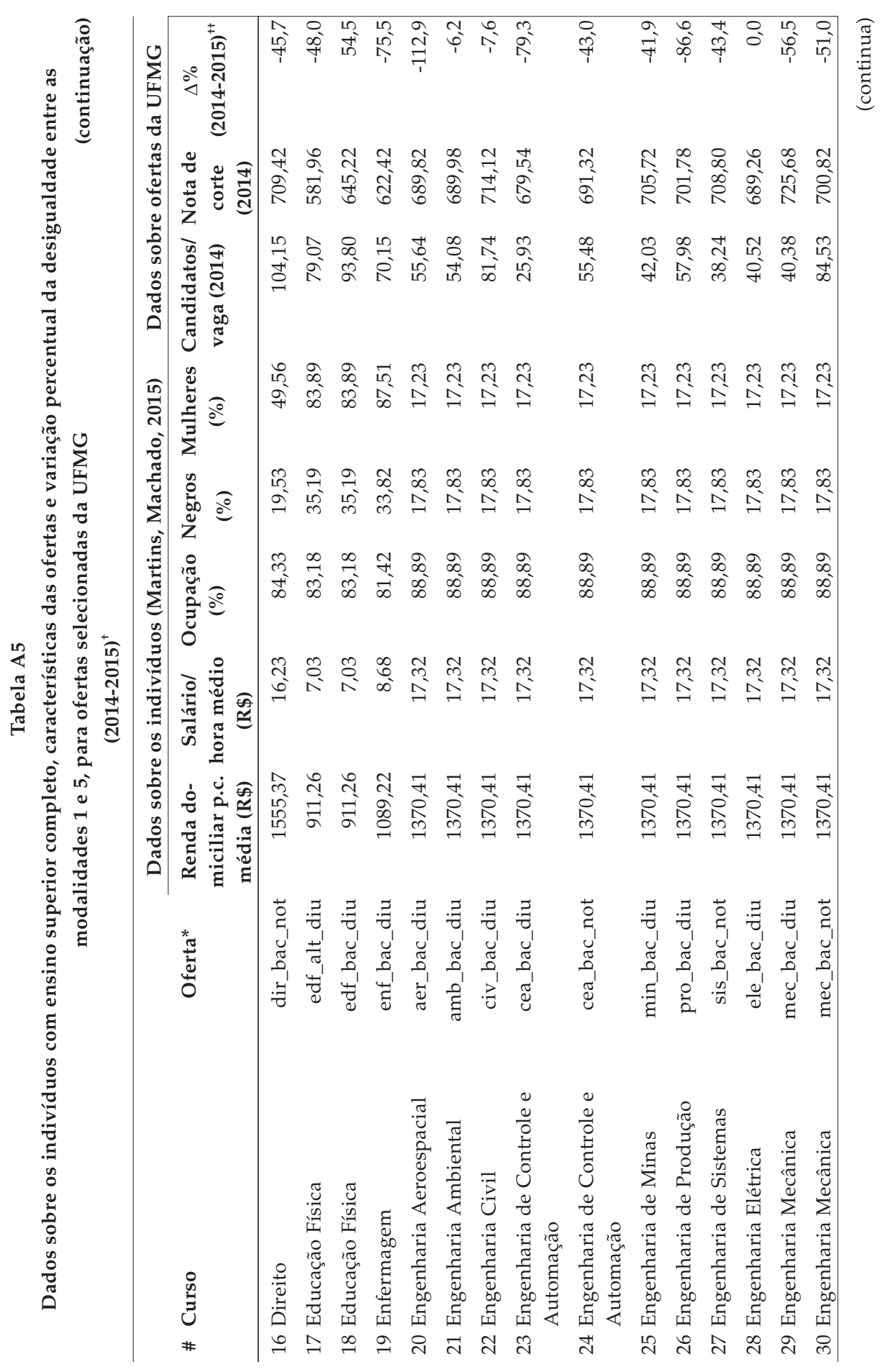

DADOS - Revista de Ciências Sociais, Rio de Janeiro, vol. 61, nํ2, 2018 


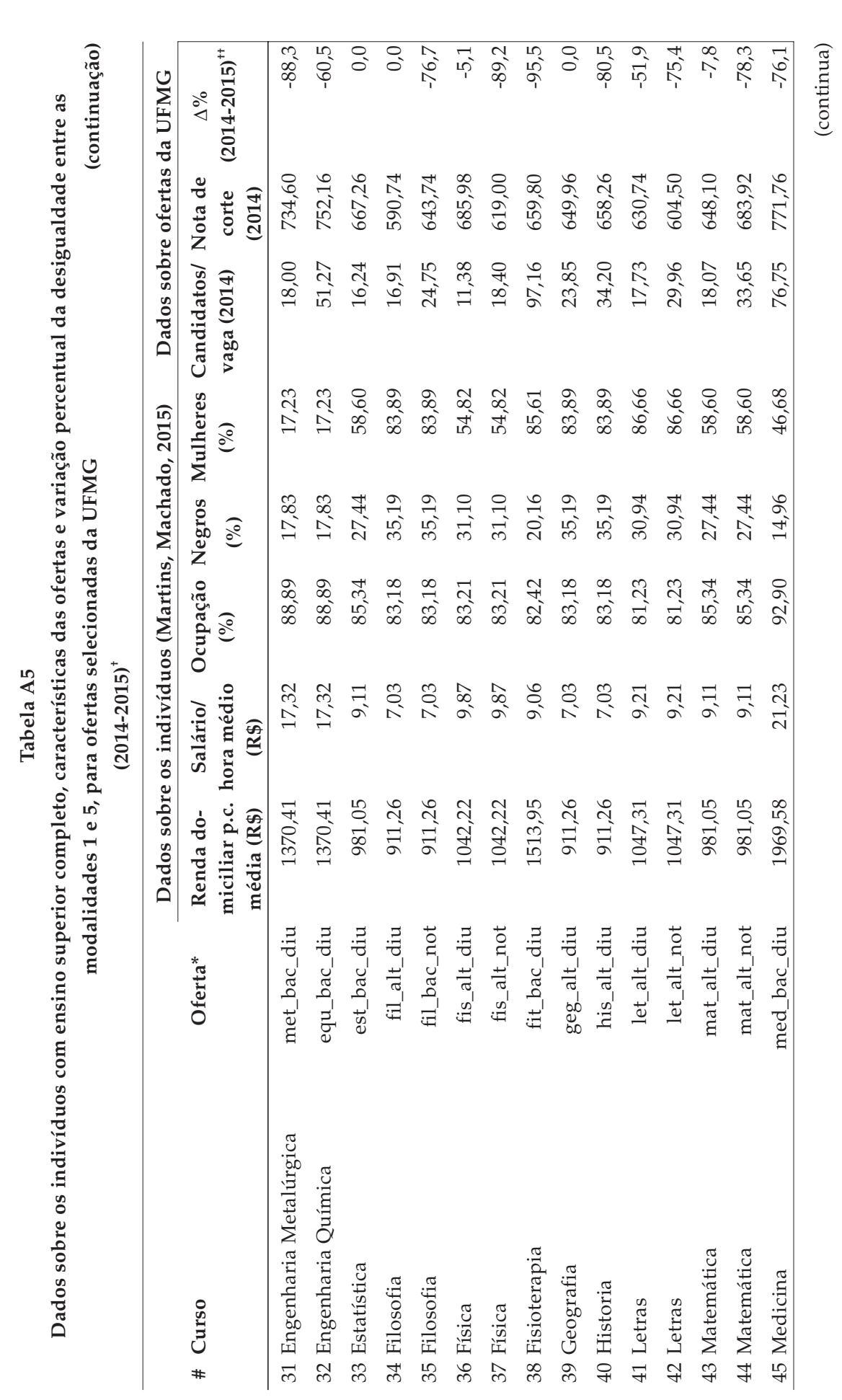


Oferta, Demanda e Nota de Corte

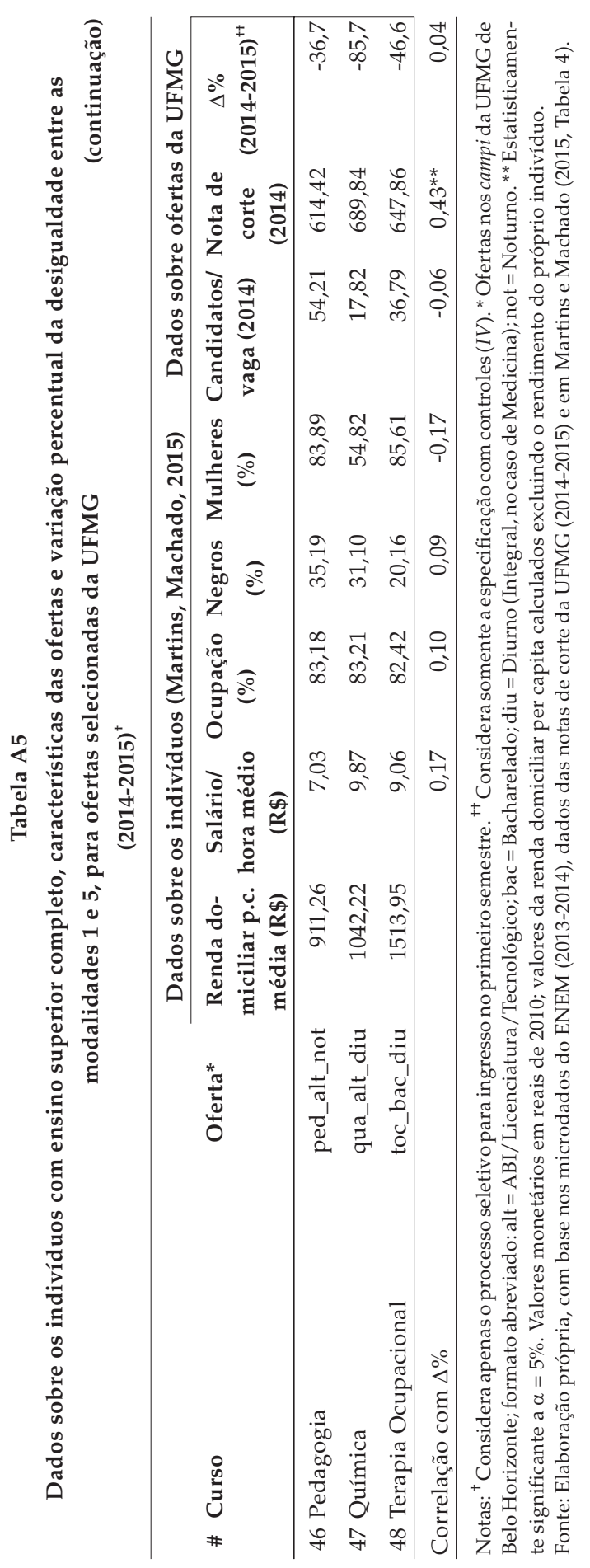

DADOS - Revista de Ciências Sociais, Rio de Janeiro, vol. 61, nํ2, 2018 


\section{Ana Karruz}

RESUMO

Oferta, demanda e nota de corte: experimento natural sobre efeitos da Lei das Cotas no acesso à Universidade Federal de Minas Gerais

Promulgada em 2012, a Lei das Cotas (LdasC) estabeleceu um padrão mínimo para as ações afirmativas no acesso ao ensino superior federal. A evidência sugere que a LdasC mudou o perfil dos discentes, sem prejuízo acadêmico. Porém, diversos aspectos dessa ação afirmativa podem comprometer sua efetividade. Este estudo ambiciona formular hipóteses sobre mecanismos pelos quais a LdasC impacta as chances de diferentes grupos acessarem a educação terciária, e dimensiona esses impactos. Mobiliza a teoria das disposições incorporadas, de Bourdieu e Passeron, para prever reações na demanda pela UFMG, e o Axioma de Identificação de Roemer, para mensurar desigualdades de oportunidade no acesso. Um experimento natural, com atribuição "como se" aleatória ao tratamento (maior percentual de vagas reservadas em 2015 em relação a 2014) para indivíduos de certa idade, e uma estratégia de pareamento (matching frontier) possibilitam inferências causais. São empregados microdados do ENEM e Censos Escolares, e dados dos candidatos a cursos presenciais oferecidos em Belo Horizonte. Os achados indicam que a LdasC: i) aqueceu a demanda pelo ensino superior entre seu público-alvo; ii) reduziu desigualdades no acesso para concluintes do ensino médio; e iii) foi mais efetiva nas ofertas com menor relação candidato/vaga, nas licenciaturas e nos cursos diurnos.

Palavras-chave: Ações afirmativas; Lei das Cotas; acesso ao ensino superior; Universidade Federal de Minas Gerais; experimento natural.

\section{ABSTRACT \\ Supply, demand and cut-off note: natural experiment on effects of the Quotas Law on access to the Federal University of Minas Gerais}

Promulgated in 2012, the Law of Quotas (LdasC) established a minimum standard for affirmative action in access to federal higher education. The evidence suggests that the LdasC changed the profile of the students, without academic damage. However, several aspects of affirmative action may compromise its effectiveness. This study aims to formulate hypotheses about the mechanisms by which LdasC impacts the chances of different groups to access tertiary education, and it measures these impacts. It mobilizes Bourdieu and Passeron's theory of embodiments to predict reactions in demand by UFMG and Roemer's Axiom of Identification to measure inequalities of 
opportunity in access. A natural experiment, with a random "as if" attribution to treatment (greater percentage of vacancies reserved in 2015 than in 2014) for individuals of a certain age, and a matching frontier allow causal inferences. They are employees of the ENEM and School Censuses, and data of the candidates for face-to-face courses offered in Belo Horizonte. The findings indicate that LdasC: i) warmed the demand for higher education among its target audience; ii) reduced access inequalities for high school graduates; and iii) it was more effective in the offers with lower candidate / vacancy ratio, in the degrees and in the day courses.

Key words: Affirmative actions; Law of Quotas; access to higher education; Federal University of Minas Gerais; natural experiment.

\section{RESUMEN}

Oferta, demanda y nota de corte: experimento natural sobre efectos de la Ley de las Cuotas en el acceso a la Universidad Federal de Minas Gerais

Promulgada en 2012, la Ley de las Cuotas (LdasC) estableció un estándar mínimo para las acciones afirmativas en el acceso a la enseñanza superior federal. La evidencia sugiere que la LdasC cambió el perfil de los discentes, sin perjuicio académico. Sin embargo, diversos aspectos de esta acción afirmativa pueden comprometer su eficacia. Este estudio ambiciona formular hipótesis sobre mecanismos por los cuales la LdasC impacta las posibilidades de que diferentes grupos accedan a la educación terciaria, y dimensione esos impactos. Moviliza la teoría de las disposiciones incorporadas, de Bourdieu y Passeron, para predecir reacciones en la demanda por la UFMG, y el Axioma de Identificación de Roemer, para medir desigualdades de oportunidad en el acceso. Un experimento natural, con atribución "como si" al azar al tratamiento (mayor porcentaje de vacantes reservadas en 2015 respecto a 2014) para individuos de cierta edad, y una estrategia de pareamiento (matching frontier) posibilitan inferencias causales. Son empleados microdados del ENEM y Censos Escolares, y datos de los candidatos a cursos presenciales ofrecidos en Belo Horizonte. Los hallazgos indican que la LdasC: i) calentó la demanda por la enseñanza superior entre su público objetivo; ii) redujo las desigualdades en el acceso a los complementos de la enseñanza media; y iii) fue más efectiva en las ofertas con menor relación candidato / vacante, en las licenciaturas y en los cursos diurnos.

Palabras clave: Acciones afirmativas; Ley de las cuotas; acceso a la enseñanza superior; Universidad Federal de Minas Gerais; experimento natural.

DADOS - Revista de Ciências Sociais, Rio de Janeiro, vol. 61, nº 2, 2018 


\section{ERRATA}

DADOS - Revista de Ciências Sociais, Rio de Janeiro, vol. 62 (1): e20190003, 2019 - ISSN: 0011-5258

http:/ / dx.doi.org/10.1590/001152582019002

No artigo "Oferta, Demanda e Nota de Corte: Experimento Natural sobre Efeitos da Lei das Cotas no Acesso à Universidade Federal de Minas Gerais", com número de DOI 10.1590/001152582018157, publicado em DADOS - Revista de Ciências Sociais, vol. 61 n 2, pp. 405-462, na página 405:

Onde se lia:

“Ana Karruzé Departamento de Ciência Política da Universidade Federal de Minas Gerais, Belo Horizonte, MG, Brasil. (e-mail: apkarruz@gmail.com)."

\section{Leia-se:}

"Departamento de Ciência Política da Universidade Federal de Minas Gerais, Belo Horizonte, MG, Brasil. (e-mail: apkarruz@gmail.com)."

Na página 406, Onde se lia:

"Renda (= 1,5 s.m. p.c.) comprovada"

Leia-se:

"Renda ( $\leq 1,5$ s.m. p.c.) comprovada"

Na página 429, Onde se lia:

“Teste Wald rejeita, a á = 5\%,Ho: Todos os âs = 0 ?"

Leia-se:

"Teste Wald rejeita, a $\alpha=5 \%$, Ho: Todos os $\beta s=0$ ?" 
Na página 433, Onde se lia:

(IV) ENEM $_{i m p}-$ Corte $_{c f t m p}=\alpha+\beta^{*}$ Ano2015 $p+\gamma \tilde{a}^{*}$ Controles $_{i}+\varepsilon_{i c f t m p}$

\section{Leia-se:}

(IV)

ENEM $_{\text {imp }}-$ Corte $_{c f t m p}=\alpha+\beta^{*}$ Ano2015 $_{p}+\gamma^{*}$ Controles $_{i}+\varepsilon_{\text {icftmp }}$

Na página 448 , Onde se lia:

“Teste Wald rejeita, a á = 5\%,Ho: Todos os âs = 0 ?"

Leia-se:

“Teste Wald rejeita, a $\alpha=5 \%$, Ho: Todos os $\beta \mathrm{s}=0$ ?"

Na página 456, Onde se lia:

“* Ofertas no campus Pampulha (Belo Horizonte); (...)"

Leia-se:

“* Ofertas nos campi da UFMG de Belo Horizonte; (...)"

Na página 456, Onde se lia:

“** Estatisticamente significante a a $=5 \% . "$

Leia-se:

“** Estatisticamente significante a $\alpha=5 \% . "$

Na página 460, Onde se lia:

“* Ofertas no campus Pampulha (Belo Horizonte); (...)"

Leia-se:

“* Ofertas nos campi da UFMG de Belo Horizonte; (...)" 
Na página 460, Onde se lia:

"** Estatisticamente significante a a $=5 \%$."

Leia-se:

“** Estatisticamente significante a $\alpha=5 \% . "$

Na página 461, Onde se lia:

"Porém, diversos aspectos dessa ação afirmativa podem comprometer sua eficácia."

Leia-se:

"Porém, diversos aspectos dessa ação afirmativa podem comprometer sua efetividade." 